Louisiana State University

LSU Digital Commons

Faculty Publications

Department of Geology and Geophysics

$11-10-2019$

\title{
Characterisation of ashes from waste biomass power plants and phosphorus recovery
}

\author{
Lijian Leng \\ Nanchang University \\ Anna A. Bogush \\ University College London \\ Amitava Roy \\ Louisiana State University \\ Julia A. Stegemann \\ University College London
}

Follow this and additional works at: https://digitalcommons.Isu.edu/geo_pubs

\section{Recommended Citation}

Leng, L., Bogush, A., Roy, A., \& Stegemann, J. (2019). Characterisation of ashes from waste biomass power plants and phosphorus recovery. Science of the Total Environment, 690 (None), 573-583.

https://doi.org/10.1016/j.scitotenv.2019.06.312

This Article is brought to you for free and open access by the Department of Geology and Geophysics at LSU Digital Commons. It has been accepted for inclusion in Faculty Publications by an authorized administrator of LSU Digital Commons. For more information, please contact ir@lsu.edu. 


\title{
and phosphorus recovery
}

\author{
Lijian Leng ${ }^{\text {a }}$, Anna A. Bogush ${ }^{\mathrm{b}}$, Amitava Roy ${ }^{\mathrm{c}}$, Julia A. Stegemann ${ }^{\mathrm{b}}$ * \\ ${ }^{\text {a }}$ School of Resources, Environmental \& Chemical Engineering and Key Laboratory \\ of Poyang Lake Environment and Resource Utilization, Ministry of Education, \\ Nanchang University, Nanchang, 330031, China \\ ${ }^{\mathrm{b}}$ Centre for Resource Efficiency \& the Environment, Department of Civil, \\ Environmental \& Geomatic Engineering, University College London, Chadwick \\ Building, Gower Street, London WC1E 6BT, UK \\ ${ }^{\mathrm{c}}$ J. Bennett Johnston, Sr., Center for Advanced Microstructures \& Devices, Louisiana \\ State University, 6980 Jefferson Hwy, Baton Rouge, LA 70806, USA \\ * Corresponding author. Tel.: +44 (0)2076797370 \\ E-mail address: j.stegemann@ucl.ac.uk (J.A. Stegemann)
}




\section{Response to reviewers' comments}

\section{Reviewer \#1:}

Manuscript Number: STOTEN-D-19-07294

Characterisation of ashes from waste biomass power plants and phosphorus recovery. The manuscript is dealing with a very interesting and important topic related to using of ashes as $\mathrm{P}$ nutrient. It is still quite few papers written on the topic on characterization and $\mathrm{P}$ recovery, and more knowledge is needed. The overall impression is that the manuscript is well organized and written. The title is adequate and covers the content of the manuscript. The objectives are well defined and the tables and the figure are well formed and arranged. The result and discussion is very comprehensive and in depth discussed. The literature referred to is relevant and show that the authors have good overview of what is published on the topic. Some written papers on phosphorus in waste products not refereed to could however give important input to the paper. The results are worth to be published.

\section{Response: We appreciate the reviewer's positive comments.}

I have only a very few comments to this manuscript:

Line 103-108: A comprehensive work on characterization of ashes, meat/bone meal and manures has been done by Brod et al. (2015) and should be referred to as work done on ashes.

Brod, E., Øgaard, A.F., Hansen, E., Wragg, D., Haraldsen, T.K. \& Krogstad, T. (2015). Waste products as alternative phosphorus fertilisers. Part I: Characterised inorganic $\mathrm{P}$ species affect fertilization effects dependent on soil pH. Nutr Cycl Agroecosyst. 103 (2):167-185.

Brod, E., Øgaard, A.F., Haraldsen, T.K. \& Krogstad, T. (2015). Waste products as alternative phosphorus fertilisers. Part II: Predicting P fertilization effects by chemical extraction. Nutr Cycl Agroecosyst. 103 (2):187-199.

Line 242: In addition to Rajendran et al. (2013) a reference to Brod et al. (2015) can be added.

Response: We have included the references mentioned by the reviewer to improve the manuscript. 


\section{Reviewer \#2:}

The paper is about characterization of ashes of incinerated meat and bone meal (MBM) and poultry litter, as well as phosphorus leaching from the ashes using sulfuric acid or nitric acid. I believe that the information can be of interest for the readers and should be published.

Response: We appreciate the reviewer's positive comments.

My comments are as follows:

Page 3, line 37: "Thermal or biological processing disposes of biomass" - consider another formulation of the text

Response: We have revised the text to make the description clearer. See Page 3, line 37 in the revised manuscript.

Page 4, line 73: the forecast for phosphorus reserves lifetime of 50-100 year is not updated. After upgrading the reserves of Morocco and West Sahara in 2010, the estimated static life time has expanded to around 350 years, ignoring any increase in phosphorus demand. See for example: IFDC (2010). World Phosphate Rock Reserves and Resources. International Fertilizer Development Centre. Technical Bulletin T-75. Please incorporate this information into the paper.

Response: We have updated the forecast for phosphorus reserves lifetime according to the information provided by the reviewer. See Page 4, Lines 72-74 in the revised manuscript.

Page 4, line 75: "around 90\%" is not correct. $71 \%$ of the reported global reserves are under the control of Morocco and West Sahara according to USA Geological Survey 2019. Response: We have updated the data and description according to the information provided by the reviewer. See Page 4, Lines 75-76 in the revised manuscript.

Page 9, line 193: the text refers to table S1. I don't find the table in the paper Page 17, line 400: the text refers to Fig S2(a). I don't find the figure in the paper Page 17, line 401: the text refers to Fig S2(b). I don't find the figure in the paper Page 17, line 405: the text refers to Fig S3(a). I don't find the figure in the paper Page 17, line 410: the text refers to Fig S4. I don't find the figure in the paper Response: This table and these figures are part of the supplementary information (SI) file. 
It is not clear if the experiments were performed in replications.

Response: We have indicated the replication of experiments in figure captions where applicable and in Page 9, line 200, and Page 10, Line 216 in the revised manuscript. 


\section{Characterisation of ashes from waste biomass power plants}

\section{and phosphorus recovery}

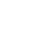

Lijian Leng ${ }^{\mathrm{a}}$, Anna A. Bogush ${ }^{\mathrm{b}}$, Amitava Roy $^{\mathrm{c}}$, Julia A. Stegemann ${ }^{\mathrm{b}}{ }^{*}$

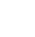

${ }^{a}$ School of Resources, Environmental \& Chemical Engineering and Key Laboratory

of Poyang Lake Environment and Resource Utilization, Ministry of Education,

Nanchang University, Nanchang, 330031, China

${ }^{\mathrm{b}}$ Centre for Resource Efficiency \& the Environment, Department of Civil,

Environmental \& Geomatic Engineering, University College London, Chadwick

Building, Gower Street, London WC1E 6BT, UK

c J. Bennett Johnston, Sr., Center for Advanced Microstructures \& Devices, Louisiana

State University, 6980 Jefferson Hwy, Baton Rouge, LA 70806, USA

* Corresponding author. Tel.: +44 (0)2076797370

E-mail address: j.stegemann@ucl.ac.uk(J.A. Stegemann) 
Abstract: Biowastes, such as meat and bone meal (MBM), and poultry litter (PL), are used as energy sources for industrial combustion in the UK. However, the biomass ashes remaining after combustion, which contain nutrients such as phosphorus, are landfilled rather than utilised. To promote their utilisation, biomass ashes from industries were characterised in terms of their elemental and mineral compositions, phosphorus extractability, and $\mathrm{pH}$-dependent leachability. These ashes were highly alkaline ( $\mathrm{pH}$ as high as 13), and rich in calcium and phosphorus. The $\mathrm{P}$ bioavailabilities in the ash evaluated by Olsen's extraction were low. Hydroxyapatite and potassium sodium calcium phosphate were identified by X-ray powder diffraction (XRD) as the major phases in the MBM and PL ashes, respectively. The leaching of $\mathrm{P}$, $\mathrm{Ca}$, and many other elements was $\mathrm{pH}$ dependent, with considerable increase in leaching below about $\mathrm{pH}$ 6. P recovery by acid dissolution (e.g., with $\mathrm{H}_{2} \mathrm{SO}_{4}$ ) seems feasible and promising; the optimized acid consumption for $\sim 90 \%$ P recovery could be as low as 3.2-5.3 $\mathrm{mol} \mathrm{H}^{+} / \mathrm{mol} \mathrm{P}$.

Keywords: incineration; fertiliser; phosphorus recovery; acid neutralisation capacity; animal manure 


\section{Introduction}

Thermal or biological processing of biomass produces heat, electricity, or liquid/gas/solid bioenergy with low net greenhouse gas emissions (Ragauskas, 2006). Wood and wood wastes, agricultural crops and their waste byproducts, animal wastes, wastes from food processing, aquatic plants, and algae are the most widely used biomass energy resources (Bogush et al., 2018; Demirbas, 2004; Huang and Yuan, 2015; Leng et al., 2018a, 2018b, 2016; Saidur et al., 2011). These biomass resources, which are currently often treated as organic wastes, can contribute significantly to the generation of renewable energy and reduction of greenhouse gas (GHG) emissions, reducing the dependency on fossil fuels (Ragauskas, 2006). The UK, for example, sets a target of $80 \%$ GHG emissions reduction over 1990 levels by 2050; the bioenergy industry contributes significantly to the achievement of these goals (Adams et al., 2011).

Consequently, recovery of energy from biomass by combustion or production of fuel, e.g., from straw, meat and bone meal, poultry litter, wood shavings, and horse bedding, is increasing in the UK, due to the mounting production of these wastes, their energy contents, and the environmental benefits of their utilisation (Oshita et al., 2016; Williams et al., 2016). However, management of ash has emerged to be one of the problems impeding the development of biomass combustion for energy (Niu et al., 2016). Since biomass ashes are rich in the nutrients phosphorus and potassium, they have been considered for use as a soil amendment on agricultural land. However, the low $\mathrm{P}$ availability, high alkalinity (e.g., $\mathrm{pH} 13$ or higher), and heavy metal contents in these ashes may restrict their direct application (Niu et al., 2016; Vassilev et al., 2013a; Bogush et al., 2018). Environmental pollution from nutrient and contaminant leaching can occur, and result in negative effects on crops, soils and water, when 
ashes are applied under soil and climatic conditions that increase environmental mobility of contaminants (Pettersson et al., 2008a; 2008b), or mobilise nutrients but do not favour their agronomic utilization, e.g., due to excessive application or an imbalance in the nutrient proportions (Bolan et al., 2010; Codling et al., 2002; Szögi et al., 2015; Williams et al., 2016). However, it is worth mentioning that environmental pollution by nutrients and contaminants has also been observed for soil fertilized with animal residues (e.g., pig slurry) directly (Cela et al., 2010; GunkelGrillon et al., 2015; Olson et al., 2010).

Meanwhile, the widespread global use of $\mathrm{P}$ fertiliser over the past century and increasing demand for $\mathrm{P}$ by agriculture threatens to deplete sources of P-bearing rock within the next century (Cordell et al., 2009; 2010; Mayer et al., 2016; Sattari et al., 2012; Tilman et al., 2001; Tilman and Lehman, 1987). Even ignoring rapidly increasing $\mathrm{P}$ demand, the estimated static lifetime of phosphorus reserves is only around 350 years (IFDC, 2010). Furthermore, the remaining reserves are highly geographically concentrated (Elser and Bennett, 2011), with around 71\% located in Morocco and Western Sahara (USGS, 2019). Therefore, sourcing P from the P consumption lifecycle and developing appropriate $\mathrm{P}$ recovery technology, especially in places with a scarcity of natural P-bearing rock such as the UK, is important to meet the increasing demand for this element (Cooper, 2014; Cordell et al., 2011; Mayer et al., 2016; Rittmann et al., 2011). Phosphorus recovery from animal residues (e.g., poultry litter, meat and bone meal) and sewage sludge, and their incineration ashes, is one of the most promising ways to increase the $\mathrm{P}$ resource security and secure future food production (Akinola, 2013; Bogush et al., 2018; Havukainen et al., 2016; Kleemann et al., 2015; Mayer et al., 2016; Tan and Lagerkvist, 2011). Cooper and Carliell-Marquet (2013) estimated that the $\mathrm{P}$ recovery potential from animal 
manure produced in the UK could be higher than national net total $\mathrm{P}$ imports; in general, the $\mathrm{P}$ value of meat and bone meal/animal bone alone is likely of a similar order of magnitude to that of a country's phosphate fertiliser imports (Cooper and Carliell-Marquet, 2013; Simons et al., 2014).

Hence, recovery of $\mathrm{P}$ from biomass ashes to produce more effective and environmentally benign $\mathrm{P}$ fertilizer is of increasing interest for both research and practice. Animal manures and manure derivatives such as ash and char have been widely explored for P recovery, with measurement of varied recovery rates and acid demands because of differences between the sources (e.g., P concentration 4.0-139 g $\mathrm{kg}^{-1}$ ) and process conditions (e.g., different acid types and loads, and solid/liquid ratios) (Table 1). For example, $\mathrm{P}$ recovery rates around $90 \%$ were obtained for animal manure char, but at acid loads in the region of $100 \mathrm{~mol} \mathrm{H}^{+} / \mathrm{mol} \mathrm{P}$ recovered (Azuara et al., 2013; Heilmann et al., 2014). Lower acid loads (3-10 mol H $\mathrm{H}^{+} / \mathrm{mol} \mathrm{P}$ recovered) were found effective for P recovery from manures and their ashes (Cohen, 2009; Kaikake et al., 2009; Kuligowski and Poulsen, 2010), which is similar to the recovery rates and acid loads for P recovery from sewage sludge ash (Petzet et al., 2012). In addition to $\mathrm{P}$ content and recovery conditions, $\mathrm{P}$ speciation in the different $\mathrm{P}$ containing resources (wastes) also influences $\mathrm{P}$ recovery performance. Elemental, mineral and chemical compositions have been used to describe $\mathrm{P}$ speciation in these materials (Bogush et al., 2018; Vassilev et al., 2013a, 2013b, 2013c), but few studies have related these results to $\mathrm{P}$ recovery performance. Furthermore, little has been reported regarding meat and bone meal (MBM) and its derivatives (e.g., ash), despite the high $\mathrm{P}$ recovery potential from these materials.

The main objectives of this research were thus:

1) to characterise biomass ashes from combustion of MBM or co-combustion of 
poultry litter (PL) in UK biomass power plants (https://biofuelwatch.org.uk/wpcontent/maps/uk-biomass.html), and

2) to examine the potential and options for P recovery from these biomass ashes.

The bioavailability of $\mathrm{P}$ from biomass ashes and potential for its recovery from the biomass ashes depends on $\mathrm{P}$ speciation and matrix composition. The biomass ashes were therefore characterised by multiple techniques, including elemental analysis, thermogravimetric analysis (TGA), determination of crystalline phases by X-ray powder diffraction (XRD), characterization of functional groups by Fourier transform infrared spectroscopy (FTIR), and measurement of acid neutralization capacity (ANC) and $\mathrm{pH}$-dependent $\mathrm{P}$ leachability, to understand the mechanisms responsible for control of P solubility. P K-edge X-ray absorption near edge spectroscopy (XANES) was used to examine the speciation of $\mathrm{P}$ in complex matrices without interference from irrelevant phases and irrespective of crystallinity.

\section{Materials and methods}

\subsection{Materials}

Five samples of biomass ash were collected from four different industrial-scale biomass power plants in the UK that use different biomass types as the energy source. The plants use moving grate incinerators with a combustion temperature of $850{ }^{\circ} \mathrm{C}$, dry discharge of bottom ash, and dry scrubbing of the flue gas. MBM1-BA and MBM2-BA were bottom ashes collected from two different plants that combust MBM; MBM2-APCr was the fly ash from the second plant. PL1-BA and PL2-BA were both bottom ashes from different power plants that co-combust PL. The moisture contents of the biomass ashes were negligible (Bogush et al., 2018). The samples were ground to $<250 \mu \mathrm{m}$ using a ball mill and then stored in air-tight containers before use.

$$
\text { Reference materials used in the mineralogical investigation included a Ward's }
$$


Science Apatite Research Mineral (www.wardsci.com; Catalogue No. 470026-560), a Moroccan apatite (carbonate apatite), and brushite $\left(\mathrm{CaHPO}_{4} \cdot 2 \mathrm{H}_{2} \mathrm{O}, 99.0 \%\right.$, SigmaAldrich).

\subsection{Biomass ash elemental composition and bioavailability of $P$}

The biomass ashes were subjected to total digestion using $\mathrm{HNO}_{3}: \mathrm{HClO}_{4}: \mathrm{H}_{2} \mathrm{O}_{2}(\mathrm{v}$, $30 \%)=5: 5: 3, \mathrm{v} / \mathrm{v})($ Leng et al., 2014) before chemical analysis for the elements of interest (Section 2.7). Separate extracts for P analysis (Section 2.7) were prepared by digestion with potassium persulfate at $150^{\circ} \mathrm{C}$ for $4.0 \mathrm{~h}$.

Olsen's method has been widely used to evaluate the bioavailability of phosphorus (Olsen et al., 1954). The extraction was conducted in triplicate for all of the biomass samples and residues from leaching at mildly acidic $\mathrm{pH}$ (Section 2.5) by mixing $2.5 \mathrm{~g}$ ash with $50 \mathrm{~mL} 0.5 \mathrm{M}$ of sodium bicarbonate $(\mathrm{pH} 8.5)$ and shaking for $30 \mathrm{~min}$ before separation of the extracts for analysis (Section 2.7).

\subsection{Biomass ash mineralogy}

The crystalline phases present in the biomass ashes and residues after leaching at mildly acidic $\mathrm{pH}$ (Section 2.5) were identified by XRD analysis on an XPERT-PRO diffractometer with an X-ray source of $\mathrm{Cu} \mathrm{K}_{\alpha}$ radiation at $40 \mathrm{KV}$ and $30 \mathrm{~mA}$. A scanning speed of $4 \mathrm{~s}$ per step and step size of $0.05^{\circ}(2 \theta)$ were used in the scanning range of $5^{\circ}-70^{\circ}(2 \theta)$. The XRD data were analysed by using Jade software version 6.0 (Materials Data Inc., Livermore, USA).

Fourier transform infrared spectra (FTIR) of the biomass ashes, residues, and reference materials were obtained on a Thermo-Fischer Scientific Nicolet 670 spectrometer in the wavelength range of $400-4000 \mathrm{~cm}^{-1}$.

Thermogravimetric analysis of the biomass ashes, residues, and reference materials was conducted by heating from room temperature to $1000{ }^{\circ} \mathrm{C}$ at a rate of $10{ }^{\circ} \mathrm{C} / \mathrm{min}$ 
under nitrogen atmosphere.

\subsection{Phosphorus speciation}

The speciation of $\mathrm{P}$ in the biomass ashes and residues after leaching at mild acidic $\mathrm{pH}$ (Section 2.5) was assessed by comparing their P K-edge X-ray absorption near edge structure (XANES) spectra with those of the reference materials. P K-edge measurements were made at the Low Energy X-ray Absorption Spectroscopy (Lexas) beamline of Louisiana State University's synchrotron research facility, the J. Bennett Johnston, Sr. Center for Advanced Microstructures and Devices (CAMD), USA. Lexas is a windowless beamline, i.e., with only a $13 \mu \mathrm{m}$ think Katon ${ }^{\mathrm{TM}}$ window separating the ring from the experimental chamber. A University of Bonn-designed Lemonnier type monochromator with InSb 111 crystals was used in measurements. The measurements were made in fluorescence by diluting the sample as necessary with boron nitride to reduce self-absorption (Oxmann, 2014). A Ketek $150 \mathrm{~mm}^{2}$ silicon drift detector was used for fluorescence measurements. The white line of reagent grade aluminum phosphate was used to calibrate the monochromator at $2152.8 \mathrm{eV}$. The parameters for the measurements were $2050 \mathrm{eV}$ to $2110 \mathrm{eV}$ with $5 \mathrm{eV}$ steps, $2110 \mathrm{eV}$ to $2142 \mathrm{eV}$ with $0.5 \mathrm{eV}$ steps, $2142 \mathrm{eV}$ to $2160 \mathrm{eV}$ with $0.1 \mathrm{eV}$ steps, from 2160 to $2180 \mathrm{eV}$ with $0.5 \mathrm{eV}$ steps, and $2180 \mathrm{eV}$ to $2250 \mathrm{eV}$ with $1 \mathrm{eV}$ steps. The integration time was from 1 to 5 seconds for adequate counting statistics. The spectra were analyzed with Athena in Demeter (Ravel and Newville, 2005).

\section{5 pH-dependent leaching}

The acid neutralization capacity (ANC) of the biomass ashes was measured to examine their $\mathrm{pH}$ responses to acid addition, and the consequent changes in the solubilities of their components of interest. This test involves adding increasing amounts of nitric acid to a series of 10 or more subsamples of the material under 
investigation (Stegemann and Côté, 1991). A single series of $5.0 \mathrm{~g}$ subsamples was weighed out for each of the biomass ashes and mixed with $30 \mathrm{~mL}$ of nitric acid diluted with deionized water to a concentration from 0 to $3 \mathrm{~N}$ (up to $18 \mathrm{meq} / \mathrm{g}$ of biomass ash) $\mathrm{HNO}_{3}$. After $48 \mathrm{~h}$ of end-over-end mixing at $30 \mathrm{rpm}$, the samples were centrifuged, and the $\mathrm{pH}$ values and conductivities of all the supernatants were measured before separation of the leachates for analysis. The solid residues corresponding to leachates with mild acidic $\mathrm{pH}(6.2,5.1,5.9,6.5$, and 6.8 for MBM1BA, MBM2-BA, MBM2-APCr, PL1-BA, and PL2-BA, respectively (Table S1) were also analysed by XRD (Section 2.3) FTIR (Section 2.3), XANES (Section 2.4), and Olsen's method (Section 2.2) after drying at $60{ }^{\circ} \mathrm{C}$.

\subsection{Acid extraction for phosphorus recovery}

To further assess acid extractability of $\mathrm{P}$ from the biomass ashes, the effects of contact time $(0-48 \mathrm{~h})$, liquid/solid ratio $\left(4-20 \mathrm{~mL} / \mathrm{g}\right.$ of ash), acid type $\left(\mathrm{HNO}_{3}\right.$ and $\left.\mathrm{H}_{2} \mathrm{SO}_{4}\right)$, and acid load (6-16 meq $\mathrm{H}^{+} / \mathrm{g}$ ash) were investigated with the volume of the extraction liquid fixed at $30 \mathrm{~mL}$. Experiments were conducted in duplicate. $\mathrm{P}$ recovery rate was defined as the percentage of $\mathrm{P}$ in the leachate as compared with that in the original ash.

\subsection{Chemical analysis of extracts and leachates}

Liquid samples from digestion, extraction, and wastewater treatment were filtered from the solids through $0.45 \mu \mathrm{m}$ membrane filters; leachates for metal analysis were acidified to $\mathrm{pH} 2$ before storage.

$\mathrm{P}$ in the filtered liquid samples was determined by colorimetry at $880 \mathrm{~nm}$, by reaction with ammonium molybdate using ascorbic acid as the reducing agent (Murphy and Riley, 1962).

Metals, including Al, B, Bi, Ba, Ca, Co, Cr, Cu, Cd, Fe, K, Mg, Li, Mn, Na, Ni, Pb, 
$\mathrm{Sr}$, and $\mathrm{Zn}$, and $\mathrm{P}$ in the extracts from total digestion of the biomass ashes and the ANC test leachates were determined by Inductively Coupled Plasma Optical Emission Spectroscopy (ICP-OES).

Anions in the ANC leachates, including $\mathrm{F}, \mathrm{Cl}^{-}, \mathrm{Br}^{-}, \mathrm{NO}_{2}{ }^{-}, \mathrm{NO}_{3}{ }^{-}, \mathrm{PO}_{4}{ }^{3-}$ and $\mathrm{SO}_{4}{ }^{2-}$, were analysed by a Dionex AQUION Ion Chromatography (IC) before acidification of the samples.

\section{All chemical analyses were conducted in triplicate with reporting of mean values.}

\section{Results and discussion}

\subsection{Biomass ash elemental composition and bioavailability of $P$}

The elemental compositions of the biomass ashes in Table 2 are typical for ashes from animal residue incineration (Bogush et al., 2018; Oshita et al., 2016; Vassilev et al., 2012; Zhang et al., 2002). Apart from P, the major elements are Al, Fe, K, Mg, $\mathrm{Mn}$, and $\mathrm{Na}$, with $\mathrm{Ca}$ as the most abundant element comprising $16-32 \%$ of the total ash.

The $\mathrm{P}$ concentrations of these ashes range from $8.3-13 \%$, which is comparable to that of some natural phosphorus rocks [e.g., 30-40\% $\mathrm{P}_{2} \mathrm{O}_{5} ; 13-17.5 \% \mathrm{P}$ (Desmidt et al., 2015; Elouear et al., 2008)]. However, Fig. 2 shows that the contents of bioavailable $\mathrm{P}$ in the ashes are less than $800 \mathrm{mg} \mathrm{P} / \mathrm{kg}$ ash, corresponding to $<0.7 \%$ of the total P.

The contents of $\mathrm{K}$ and, especially, $\mathrm{Mg}$, in the PL ashes are higher than those of the MBM ashes. Some differences between the compositions of ashes from different MBM incineration plants can also be observed, e.g., MBM1-BA has higher contents of $\mathrm{Ca}$ and $\mathrm{P}$, and lower contents of $\mathrm{K}$ and Na compared to MBM2-BA, showing the effects of variations in the original MBM materials. Minor elements such as B, Zn, Sr, $\mathrm{Ba}$, and $\mathrm{Cu}$ are in the range of $100-1100 \mathrm{mg} / \mathrm{kg}$, while trace elements such as $\mathrm{Bi}, \mathrm{Cd}$, 
$\mathrm{Cr}, \mathrm{Co}, \mathrm{Li}, \mathrm{Ni}$, and $\mathrm{Pb}$ are $<100 \mathrm{mg} / \mathrm{kg}$.

\subsection{Biomass ash mineralogy}

Fig. 1(a) shows that the dominant phase identified in the MBM ashes by XRD is hydroxyapatite (HAP), which is consistent with the high contents of $\mathrm{Ca}$ and $\mathrm{P}$. Hydroxyapatite, with some carbonation, is the principal mineral in bone (e.g., Elliott, 2002), and increases in crystallinity with heating. Both $\beta$-tricalcium phosphate $[\beta-$ $\left.\mathrm{Ca}_{3}\left(\mathrm{PO}_{4}\right)_{2}, \beta-\mathrm{TCP}\right]$ and HAP were identified by XRD as the major phases in either dried or calcined bones (Brod et al., 2015; Rajendran et al., 2013). XRD identified potassium sodium calcium phosphate $\left[\mathrm{KNaCa}_{2}\left(\mathrm{PO}_{4}\right)_{2}\right]$ as the main phase in the PL ashes. This phase is also identified as the major mineral phase after combustion of $\mathrm{P}$ and Ca-bearing biomass at a temperature of $815{ }^{\circ} \mathrm{C}$ (Kongsomart et al., 2016). The solubility of apatite varies significantly depending on its content of other anions (e.g., $\mathrm{CO}_{3}{ }^{2-}, \mathrm{Cl}^{-}$or $\mathrm{F}^{-}$) (Magalhães and Williams, 2007), but $\mathrm{Ca}_{5}\left(\mathrm{PO}_{4}\right)_{3}(\mathrm{OH})$, which has $\mathrm{K}_{\mathrm{sp}}$ $=3.98 \times 10^{-59}$ (Chow, 2001; Delvasto et al., 2006) might be expected to have low bioavailability, as was observed for the biomass ashes (Section 3.1). No data about bioavailability was found for $\mathrm{KNaCa}_{2}\left(\mathrm{PO}_{4}\right)_{2}$.

A comparison of the Moroccan apatite FTIR spectrum with those of the ashes [Fig. 1(b)] shows that all are dominated by the ca. $1030 \mathrm{~cm}^{-1}$ (anti-symmetric stretch $\Upsilon_{3}$ ) band, with the $\Upsilon_{1}$ (ca. $\left.960 \mathrm{~cm}^{-1}\right)$ and symmetric stretch $\Upsilon_{4}$ bands $\left(\mathrm{F}_{2}\right.$ bend 650$525 \mathrm{~cm}^{-1}$ ) also being conspicuous; the resemblance to the reference material is most obvious for MBM1-BA and MBM2-APCr. However, all phosphate bands show some shift, indicating variations in composition, e.g., substitution of $\mathrm{CO}_{3}{ }^{2-}$ in the crystal structure. The $\mathrm{CO}_{3}{ }^{2-}$ ion can be found in the channels (A type) of the hexagonal crystal structure of apatite, or substitutes for the phosphate ion (B type). With B type carbonate apatite, there is a doublet around $1430 \mathrm{~cm}^{-1}$ (Fleet, 2009), as seen in the 
Moroccan apatite. PL1-BA thus seems to contain carbonate apatite whereas the other ashes showed only hydroxyapatite. The $\mathrm{OH}^{-}$peak at $3420 \mathrm{~cm}^{-1}$ in all FTIR spectra is quite weak, but the derivative thermogravimetric (DTG) curves [Fig. 1(c)] show that all ashes have mass loss peaks in the region $200{ }^{\circ} \mathrm{C}$ to $400{ }^{\circ} \mathrm{C}$. A comparison with apatite standards used in this study (not shown) and data from the literature suggests this peak is from the $\mathrm{OH}$ in the apatite in the ashes. The DTG curves also have doublets, which vary in strength depending on the biomass ash, in the region $600^{\circ} \mathrm{C}$ to $800^{\circ} \mathrm{C}$, one of which is likely from the carbonate in the apatite structure, whereas the other one is calcium carbonate (Peters et al., 2000).

Previous studies have also found hydroxyapatite and $\mathrm{KNaCa}_{2}\left(\mathrm{PO}_{4}\right)_{2}$ (Bogush et al., 2018; Coutand et al., 2008; Komiyama et al., 2013; Oshita et al., 2016; Sugiyama et al., 2016), but also other minerals, e.g., $\mathrm{Ca}_{3}\left(\mathrm{PO}_{4}\right)_{2}$ in ashes from MBM or animal manure combustion (Coutand et al., 2008; Sugiyama et al., 2016) and $\mathrm{Ca}_{9} \mathrm{MgK}\left(\mathrm{PO}_{4}\right)_{7}$ in manure ashes (Komiyama et al., 2013; Oshita et al., 2016).

XRD also showed portlandite $\left[\mathrm{Ca}(\mathrm{OH})_{2}\right]$ in the MBM ashes, which is corroborated by the $3643 \mathrm{~cm}^{-1}$ FTIR band, suggestive of $\mathrm{OH}^{-}$in $\mathrm{Ca}(\mathrm{OH})_{2}$ for all ashes but PL1-BA. The single similar carbonate band around $1430 \mathrm{~cm}^{-1}\left(\Upsilon_{3}\right)$ in the FTIR spectra of all ashes except PL1-BA is typical of calcite, corresponding to calcite $\left(\mathrm{CaCO}_{3}\right)$ peaks in the XRD patterns except PL ashes.

$\mathrm{XRD}$ indicates sulphate to be present as calcium sulphate $\left(\mathrm{CaSO}_{4}\right)$ in all $\mathrm{MBM}$ ashes (Table 3), and arcanite $\left(\mathrm{K}_{2} \mathrm{SO}_{4}\right)$ in the MBM2 and PL ashes. The FTIR spectra of MBM2-BA and PL2-BA are unlike those of the other ashes due to higher amounts of arcanite, which presents as peaks at $618 \mathrm{~cm}^{-1}, 1100 \mathrm{~cm}^{-1}$ and $1197 \mathrm{~cm}^{-1}$. Sulfate breakdown may be responsible for the peak observed in the DTG at $931^{\circ} \mathrm{C}(\mathrm{MBM} 2-$ APCr). 
XRD also shows quartz $\left(\mathrm{SiO}_{2}\right)$ in the PL ashes and MBM1-BA, and abundant halite $(\mathrm{NaCl})$ in $\mathrm{MBM} 2-\mathrm{APCr}$ and MBM2-BA.

\subsection{Phosphorus speciation}

Fig. 1(d) shows the phosphorus K-edge XANES spectra of the samples along with that of the Ward's Science apatite. The white line position (A) of the latter is $2151.84 \mathrm{eV}$, while that of the ash samples ranges from $2151.67 \mathrm{eV}$ to $2151.85 \mathrm{eV}$. The phosphate white line is from resonance between $1 \mathrm{~s}$ and higher energy $t_{2} *$ orbitals, while the peak around $2168 \mathrm{eV}$ is from the P-O bond. The location and intensity of the $\mathrm{C}$ and $\mathrm{D}$ maxima depend on the composition and crystallinity of the phosphate phases (Ingall et al., 2011). These ashes thus have different phosphate compositions. Linear combination fitting of the spectrum of the MBM1-BA ash shows it to be principally composed of apatite, but the fit of apatite was not as good for the other ashes. The inflection of the shoulder at $\sim 2155 \mathrm{eV}$ correlates with the $\mathrm{Ca} / \mathrm{P}$ ratio of the structure (Franke and Hormes, 1995); consequently, the PL ashes, which are indicated by $\mathrm{XRD}$ to contain $\mathrm{KNaCa}_{2}\left(\mathrm{PO}_{4}\right)_{2}$, appear to have a lower $\mathrm{Ca} / \mathrm{P}$ ratio than the $\mathrm{MBM}$ ashes, in which $\mathrm{Ca}_{5}\left(\mathrm{PO}_{4}\right)_{3}(\mathrm{OH})$ was identified as the main P-bearing mineral.

There are some contradictions when comparing mineralogy results obtained from different analytical techniques. The variance between mineralogical analyses can be expected when applying different techniques to very small samples, particularly for complex materials such as these. Mineral phases identified by XRD were used in the following discussions unless specified otherwise.

\section{$3.4 \mathrm{pH}$ dependent leaching and characterisation of the leached residues}

The leachate $\mathrm{pH}$ values resulting from the discrete acid loading (on the secondary ordinate in Figs. 3 and 4) suggest a small, near vertical, plateau corresponding to neutralisation of the abundant $\mathrm{Ca}(\mathrm{OH})_{2}$ in the $\mathrm{MBM}$ ash at $\mathrm{pH} \sim 12$; this plateau is 
absent for the PL ashes, which contain little $\mathrm{Ca}(\mathrm{OH})_{2}$ (section 3.2).

A second $\mathrm{pH}$ plateau at $\sim 7$ may be attributable to several different phenomena. Dissolution of the small component of calcite in the ashes, which will yield a $\mathrm{pH}$ lower than that of 8.3 expected in equilibrium with the atmosphere since the leaching tubes are sealed, likely contributes to this plateau. For the MBM ashes, the plateau also reflects dissolution of $\mathrm{Ca}_{5}\left(\mathrm{PO}_{4}\right)_{3}(\mathrm{OH})$, which has an equilibrium $\mathrm{pH}$ of $\sim 7.5$ (based on the $\mathrm{K}_{\mathrm{sp}}$ noted above). Perhaps most importantly, a phosphate buffer system will result from dissolution of the apatite, and, especially, $\mathrm{KNaCa}_{2}\left(\mathrm{PO}_{4}\right)_{2}$. The second plateau is more apparent for the PL ashes, which had an acid neutralization capacity of 9-10 meq $\mathrm{H}^{+} / \mathrm{g}$ to $\mathrm{pH} 4$, whereas it was only $5-6 \mathrm{H}^{+}$meq/g for the MBM ashes. There is a third $\mathrm{pH}$ plateau, below $\mathrm{pH} 4$.

Fig. 3 shows that sulfate, released at high $\mathrm{pH}$ by dissolution of $\mathrm{K}_{2} \mathrm{SO}_{4}$, drops in concentration below $\mathrm{pH} 8$, likely due to precipitation of gypsum $\left(\mathrm{CaSO}_{4} \cdot 2 \mathrm{H}_{2} \mathrm{O} ; \mathrm{K}_{\mathrm{sp}}=\right.$ $2.62 \times 10^{-5}$; Harouaka et al., 2014), as Ca enters solution from calcite and the phosphate minerals (Fig. 4). Since there is little $\mathrm{K}_{2} \mathrm{SO}_{4}$ to dissolve from MBM1-BA, $\mathrm{Ca}$ is not precipitated and its leached concentration is therefore higher than for the other ashes.

Fig. 3 shows constant concentrations of chloride regardless of $\mathrm{pH}$ for each biomass ash, consistent with the presence of $\mathrm{NaCl}$ identified by XRD. $\mathrm{Na}$ and $\mathrm{K}$ are also initially released from $\mathrm{NaCl}$ and $\mathrm{K}_{2} \mathrm{SO}_{4}$, but their concentrations rise slightly as the $\mathrm{pH}$ falls in the MBM ash leachates, and increase dramatically below $\mathrm{pH} 8$ in the PL ash leachates. P (Fig. 4, and phosphate, Fig. 3) concentrations are seen to be low above $\mathrm{pH} \sim 4$, and then increase as the phosphate minerals dissolve with further acid addition. Release of $\mathrm{Na}$ and $\mathrm{K}$ with $\mathrm{P}$ from dissolution of the $\mathrm{KNaCa}_{2}\left(\mathrm{PO}_{4}\right)_{2}$ in the $\mathrm{PL}$ ashes would be expected, but the increases in their concentrations before the 
concentration of $\mathrm{P}$ starts to rise suggest that the dissolution of $\mathrm{KNaCa}_{2}\left(\mathrm{PO}_{4}\right)_{2}$ is incongruent, with selective loss of $\mathrm{K}$ and $\mathrm{Na}$, or that this mineral dissolves and reprecipitates, e.g., as brushite $\left(\mathrm{CaHPO}_{4} \cdot 2 \mathrm{H}_{2} \mathrm{O}\right)$ (Johnsson and Nancollas, 1992).

$\mathrm{Mg}, \mathrm{Ba}$ and $\mathrm{Sr}$ (Fig. S1) seem to be mainly released in association with the $\mathrm{pH} \sim 7$ plateau. They may substitute for $\mathrm{Ca}$ in calcite or phosphate minerals and are released when those dissolve. $\mathrm{Cu}$ and $\mathrm{Zn}$ form phosphates of low solubility and are mainly released below $\mathrm{pH} 4$; the leaching rates of these elements were undetectable or at very low level at pH 8-12 from MBM1-BA (Fig. S1), because of the relatively low total contents of minor elements in this ash (Table 2). The concentrations of Fe were almost undetectable, and those of $\mathrm{Al}$ were negligible, in the leachates from the $\mathrm{MBM}$ ashes and PL2-BA. Iron oxides have low solubility, and it is possible that $\mathrm{Fe}_{3}\left(\mathrm{PO}_{4}\right)_{2} \cdot 8 \mathrm{H}_{2} \mathrm{O} / \mathrm{FePO}_{4}, \mathrm{AlPO}_{4}, \mathrm{~Pb}_{5}\left(\mathrm{PO}_{4}\right)_{3}(\mathrm{OH}) / \mathrm{Pb}_{3}\left(\mathrm{PO}_{4}\right)_{2}$, and $\mathrm{Zn}_{3}\left(\mathrm{PO}_{4}\right)_{2}$, which have low solubility, may exist in the original ashes or were formed as secondary precipitates during the test (Deydier et al., 2003; Parhi et al., 2006; Wilfert et al., 2015).

XRD of the residues in Fig. 1(a) from leaching at mildly acidic pH (5.1-6.8; Section 2.5) shows precipitation of $\mathrm{CaHPO}_{4} \cdot 2 \mathrm{H}_{2} \mathrm{O}\left[\mathrm{K}_{\mathrm{sp}}=2.57 \times 10^{-7}\right.$; (Chow, 2001)], which forms under acidic conditions (Johnsson and Nancollas, 1992). Dorozhkin's dissolution mechanism for hydroxyapatite (Eqs. 1-3) demonstrates that $\mathrm{Ca}_{5}\left(\mathrm{PO}_{4}\right)_{3}(\mathrm{OH})$ would produce $\mathrm{Ca}_{3}\left(\mathrm{PO}_{4}\right)_{2}\left(\mathrm{~K}_{\mathrm{sp}}=3.16 \times 10^{-26}\right.$ for $\alpha-\mathrm{Ca}_{3}\left(\mathrm{PO}_{4}\right)_{2}$ and $\mathrm{K}_{\mathrm{sp}}$ $=1.26 \times 10^{-29}$ for $\left.\beta-\mathrm{Ca}_{3}\left(\mathrm{PO}_{4}\right)_{2}(\mathrm{Chow}, 2001)\right)$ at the first stage and then addition of additional acid would yield metastable $\mathrm{CaHPO}_{4}$, and finally the dissolution of $\mathrm{CaHPO}_{4}$ (Dorozhkin, 2012; 1997). Brushite solubility can markedly rise with a decrease in $\mathrm{pH}$ from 6 to 3 (Kuz'mina et al., 2013) and at lower $\mathrm{pH}$ it dissolves linearly (Figs. 3 and 4). 
$2 \mathrm{Ca}_{5}\left(\mathrm{PO}_{4}\right)_{3}(\mathrm{OH})+2 \mathrm{H}^{+} \rightarrow 3 \mathrm{Ca}_{3}\left(\mathrm{PO}_{4}\right)_{2}+\mathrm{Ca}^{2+}+2 \mathrm{H}_{2} \mathrm{O}$

$\mathrm{Ca}_{3}\left(\mathrm{PO}_{4}\right)_{2}+2 \mathrm{H}^{+} \rightarrow 2 \mathrm{CaHPO}_{4}+\mathrm{Ca}^{2+}$

$\mathrm{CaHPO}_{4}+\mathrm{H}^{+} \rightarrow \mathrm{H}_{2} \mathrm{PO}_{4}^{-}+\mathrm{Ca}^{2+}$

The presence of $\mathrm{CaHPO}_{4} \cdot 2 \mathrm{H}_{2} \mathrm{O}$ in the residues after leaching at mildly acidic $\mathrm{pH}$ (pH 5.1-6.8) was verified by multiple techniques. Fig. 1(a) shows that it dominates the XRD patterns of the leached residues, while the peak intensities for $\mathrm{Ca}_{5}\left(\mathrm{PO}_{4}\right)_{3}(\mathrm{OH})$ in MBM ashes are reduced and $\mathrm{KNaCa}_{2}\left(\mathrm{PO}_{4}\right)_{2}$ in $\mathrm{PL}$ ashes have almost disappeared. The prominent peak around $1650 \mathrm{~cm}^{-1}$ found in the FTIR spectra of all the leached residues as seen in [Fig. 1 (b)] corresponds to the molecular $\mathrm{H}_{2} \mathrm{O}$ peak from $\mathrm{CaHPO}_{4} \cdot 2 \mathrm{H}_{2} \mathrm{O}$ at $1645.48 \mathrm{~cm}^{-1}$. The precipitation of $\mathrm{CaHPO}_{4} \cdot 2 \mathrm{H}_{2} \mathrm{O}$ is also evident in the DTG traces for the leached residues of all the ashes as a peak at $\sim 183^{\circ} \mathrm{C}$ [Fig. 1 (c)], with the amount ranging from 21.6-24.2\%. Finally, the P K-edge XANES spectra [Fig. 1(d)] confirm that different phosphate phases are present in the leached residues than the original ashes, although fitting to estimate the exact $\mathrm{P}$ composition is difficult as several phosphate phases are present. Although $\mathrm{CaHPO}_{4} \cdot 2 \mathrm{H}_{2} \mathrm{O}\left(\mathrm{K}_{\mathrm{sp}}=2.57 \times 10^{-7}\right)$ in the residues is more soluble than $\mathrm{Ca}_{5}\left(\mathrm{PO}_{4}\right)_{3}(\mathrm{OH})\left(\mathrm{K}_{\mathrm{sp}}=3.98 \times 10^{-59}\right)$, the bioavailable $\mathrm{P}$ in the solid residues separated from the mildly acidic leachates remained low at $<1400 \mathrm{mg} \mathrm{P} / \mathrm{kg}$ ash (Fig. 2). It is noteworthy that $\mathrm{CaHPO}_{4} \cdot 2 \mathrm{H}_{2} \mathrm{O}$ can transform back to $\mathrm{Ca}_{5}\left(\mathrm{PO}_{4}\right)_{3}(\mathrm{OH})$ or $\mathrm{Ca}_{3}\left(\mathrm{PO}_{4}\right)_{2}$ in an alkaline and calcium-rich environment (Štulajterová and Medvecký, 2008).

During leaching, the water-soluble $\mathrm{NaCl}, \mathrm{K}_{2} \mathrm{SO}_{4}$, and acid-soluble calcite and $\mathrm{Ca}(\mathrm{OH})_{2}$ were not found in the leached residues, as shown in Fig. 1(a), but gypsum $\left(\mathrm{CaSO}_{4} \cdot 2 \mathrm{H}_{2} \mathrm{O}\right)$ and $\mathrm{SiO}_{2}$ remained, as they are acid-insensitive over the $\mathrm{pH}$ range studied. The absence of the $618 \mathrm{~cm}^{-1}$ and $1195 \mathrm{~cm}^{-1}$ bands in the FTIR spectra of the leached residues [Fig. 1(b)] indicate the dissolution of the sulfate phases. The $713 \mathrm{~cm}^{-}$ 
${ }^{1}$ carbonate band from calcite is very weak to non-existent in the residues [Fig. 1(b)]. In the thermogravimetric analysis of the leached residues, all the mass loss occurred by $600^{\circ} \mathrm{C}$, and the absence of a calcite peak [Fig. 1(c)] reflect complete dissolution of calcite at the lower $\mathrm{pH}$.

To summarize, $\mathrm{NaCl}$ and $\mathrm{K}_{2} \mathrm{SO}_{4}$ present in ashes dissolved readily with water leaching. Other chemical components dissolved with decreasing $\mathrm{pH}$ or increasing acid addition. Alkaline $\mathrm{CaCO}_{3}$ and $\mathrm{Ca}(\mathrm{OH})_{2}$ were neutralized at the first plateau and followed by the dissolution of $\mathrm{Ca}_{5}\left(\mathrm{PO}_{4}\right)_{3}(\mathrm{OH})$ and $\mathrm{KNaCa}_{2}\left(\mathrm{PO}_{4}\right)_{2}$ to produce $\mathrm{CaHPO}_{4} \cdot 2 \mathrm{H}_{2} \mathrm{O}$ at $\mathrm{pH} \sim 7$, which continued to dissolve with releasing of $\mathrm{P}$ to the leachate from $\mathrm{pH} \sim 4 . \mathrm{Mg}, \mathrm{Ba}$ and $\mathrm{Sr}$ mainly released in association with the $\mathrm{pH} \sim 7$ plateau while the release of $\mathrm{Fe}, \mathrm{Al}, \mathrm{Zn}$, and $\mathrm{Cu}$ became evident at $\mathrm{pH} 4$.

\subsection{Phosphorus recovery from biomass ash}

$\mathrm{P}$ release in the ANC test can be used to estimate the $\mathrm{P}$ recovery potential from the biomass ashes studied. Phosphorus recovery was found to be linearly dependent on the leachate $\mathrm{pH}$ below $\mathrm{pH} 4$, attaining $40-50 \%$ at $\mathrm{pH} 3$, and $\sim 100 \%$ P recovery at $\mathrm{pH} \sim 1$ [Fig. S2(a)]. Determination of the acid consumption per unit of $\mathrm{P}$ recovered [Fig. S2(b)] is essential to assess the economic feasibility of the recovery process, and ranged from 9-14 meq $\mathrm{H}^{+} / \mathrm{g}$ ash, assuming that the other ashes follow the trend established to $100 \%$ recovery for PL1-BA.

Investigation of the contact time showed that $\mathrm{P}$ recovery reached $75-95 \%$ of its highest value within several minutes [Fig. S3(a)], but the $\mathrm{pH}$ needed several hours to reach steady state [Fig. S3(b)]. This implies that $\mathrm{P}$ could be recovered promptly before surplus acid is consumed by the solid ash residue.

Solid/liquid (S/L) ratio also plays a significant role in P recovery; less acid was consumed per unit of $\mathrm{P}$ recovered at lower $\mathrm{S} / \mathrm{L}$ ratios because of more efficient mixing 
411 (Fig. S4). For example, results show that $10-20 \%$ less acid will be needed at S/L ratio of 0.05 , than at a $\mathrm{S} / \mathrm{L}$ of 0.1 , which is the ratio that has been widely used for $\mathrm{P}$ dissolution from biomass ashes (Oshita et al., 2016; Sugiyama et al., 2016). Unfortunately, a lower S/L ratio also produces a larger amount of leachate with a lower $\mathrm{P}$ concentration, which could make the recycling of $\mathrm{P}$ and the subsequent wastewater treatment much more difficult.

$\mathrm{HNO}_{3}$ and $\mathrm{H}_{2} \mathrm{SO}_{4}$ were therefore applied at $\mathrm{S} / \mathrm{L} 0.1$, with a contact time of $2 \mathrm{~h}$, to assess the influence of the acid type on $\mathrm{P}$ recovery and acid consumption. $\mathrm{H}_{2} \mathrm{SO}_{4}$ seems to be more efficient for P leaching from these biomass ashes compared with $\mathrm{HNO}_{3}$ particularly at lower acid load (Fig. 5). During the $\mathrm{H}_{2} \mathrm{SO}_{4}$ process, the precipitation of gypsum promotes the dissolution of apatite, and facilitates the separation of the product. By comparison, separation of dissolved $\mathrm{Ca}\left(\mathrm{NO}_{3}\right)_{2}$ formed during $\mathrm{HNO}_{3}$ leaching is difficult. At $\mathrm{H}_{2} \mathrm{SO}_{4}$ load of $14 \mathrm{meq} \mathrm{H}^{+} / \mathrm{g}$ ash, the acid consumption is in the range of $3.2-5.3 \mathrm{~mol} \mathrm{H}^{+} / \mathrm{mol} \mathrm{P}$ (Fig. 5), which is comparable with those reported in previous studies when animal manures or their derivatives (e.g., ashes) (Table 1) or sewage sludge ashes (Petzet et al., 2012) were used for P recovery. Meanwhile, P recovery of $\sim 90 \%$ or higher was achieved at this acid load.

\subsection{Economic considerations}

In the phosphorus industry, phosphoric acid is the basic starting raw material for production, which is normally produced from phosphate rock. The wet process is the most commonly used phosphoric acid production process, in which $\mathrm{H}_{2} \mathrm{SO}_{4}$ dissolves $\mathrm{Ca}_{5}\left(\mathrm{PO}_{4}\right)_{3}(\mathrm{~F}, \mathrm{Cl}, \mathrm{OH})$, followed with purification and condensation to produce phosphoric acid $\left(\mathrm{H}_{3} \mathrm{PO}_{4}\right)$ and byproduct phosphogypsum (Tayibi et al., 2009). $\mathrm{Ca}_{5}\left(\mathrm{PO}_{4}\right)_{3} \mathrm{~F}$ is the dominant component of natural phosphate rock and its dissolution mechanisms during wet-process phosphoric acid production can be described by Eqs. 
4-7 (Dorozhkin, 1996), which are similar to those for $\mathrm{Ca}_{5}\left(\mathrm{PO}_{4}\right)_{3}(\mathrm{OH})($ Eqs. 1-3). The overall reaction can be described by Eq. 8 (Wu et al., 2018).

$$
2 \mathrm{Ca}_{5}\left(\mathrm{PO}_{4}\right)_{3}(\mathrm{~F}, \mathrm{OH})+2 \mathrm{H}^{+} \rightarrow 3 \mathrm{Ca}_{3}\left(\mathrm{PO}_{4}\right)_{2}+\mathrm{Ca}^{2+}+2 \mathrm{HF}, \mathrm{H}_{2} \mathrm{O}
$$

$$
\mathrm{Ca}_{3}\left(\mathrm{PO}_{4}\right)_{2}+2 \mathrm{H}^{+} \rightarrow 2 \mathrm{CaHPO}_{4}+\mathrm{Ca}^{2+}
$$

$\mathrm{CaHPO}_{4}+\mathrm{H}^{+} \rightarrow \mathrm{H}_{2} \mathrm{PO}_{4}^{-}+\mathrm{Ca}^{2+}$

$\mathrm{H}_{2} \mathrm{PO}_{4}^{-}+\mathrm{H}^{+} \rightarrow \mathrm{H}_{3} \mathrm{PO}_{4}$

$\mathrm{Ca}_{10}\left(\mathrm{PO}_{4}\right)_{6}(\mathrm{~F}, \mathrm{OH})_{2}+10 \mathrm{H}_{2} \mathrm{SO}_{4}+\mathrm{nH}_{2} \mathrm{O} \rightarrow 10 \mathrm{CaSO}_{4} \cdot \mathrm{nH}_{2} \mathrm{O}+6 \mathrm{H}_{3} \mathrm{PO}_{4}+2 \mathrm{HF}, \mathrm{H}_{2} \mathrm{O}$

The theoretical acid consumption for the wet-process phosphoric acid production is $3.3 \mathrm{~mol} \mathrm{H} / \mathrm{mol} \mathrm{P}$ or $1.67 \mathrm{~mol} \mathrm{H}_{2} \mathrm{SO}_{4} / \mathrm{mol} \mathrm{H}_{3} \mathrm{PO}_{4}$. If the final product is $\mathrm{H}_{2} \mathrm{PO}_{4}{ }^{-}$, the consumption drops to $2.3 \mathrm{~mol} \mathrm{H} \mathrm{H}^{+} / \mathrm{mol} \mathrm{P}$, which is the lowest acid addition needed to dissolve all P into the aqueous phase. However, the processes described by Eqs. 6 and 7 proceed at the same time; thus, the lowest theoretical acid consumption for $\mathrm{P}$ dissolution from $\mathrm{Ca}_{5}\left(\mathrm{PO}_{4}\right)_{3}(\mathrm{~F}, \mathrm{OH})$ would be 2.3-3.3 mol H $\mathrm{H}^{+} / \mathrm{mol} \mathrm{P}$. Considering the presence of minerals such as $\mathrm{CaCO}_{3}, \mathrm{MgCO}_{3}, \mathrm{CaO}$, and $\mathrm{MgO}$ in natural phosphate rock, the consumption would be $>2.3-3.3 \mathrm{~mol} \mathrm{H} / \mathrm{mol} \mathrm{P}$ depending on the content of acid-consuming components, which is comparable to that of dissolution of MBM ashes (3.2-4.2 $\mathrm{mol} \mathrm{H} \mathrm{H}^{+} / \mathrm{mol} \mathrm{P)}$. Furthermore, the dissolution of MBM ashes (composed of $\left.\mathrm{Ca}_{5}\left(\mathrm{PO}_{4}\right)_{3}(\mathrm{OH})\right)$ would not be complicated by the presence of fluorine, which is abundant in phosphate rock. Therefore, $\mathrm{P}$ recovery from MBM ashes by direct acid dissolution seems very promising and worth further investigation.

\section{Conclusions}

Hydroxyapatite $\left[\mathrm{Ca}_{5}\left(\mathrm{PO}_{4}\right)_{3}(\mathrm{OH})\right]$ and potassium sodium calcium phosphate $\left[\mathrm{KNaCa}_{2}\left(\mathrm{PO}_{4}\right)_{2}\right]$ seem to be the main mineral phases in the MBM and PL ashes, respectively, with low bioavailability of $\mathrm{P}$. Phosphate leaching is $\mathrm{pH}$ dependent and 
significant recovery was experienced at $\mathrm{pH}<4$. Major heavy metals such as $\mathrm{Cu}$ and Zn demonstrated similar leaching behavior as $\mathrm{P}$. A substantial proportion of the $\mathrm{P}$ remaining in the solid residues after acid leaching was transformed to brushite, but its bioavailability increased only slightly.

It appears that secondary $\mathrm{P}$, for industrial production of fertilizer or other chemicals, could be recovered from MBM and PL ashes by acid dissolution (particularly by $\mathrm{H}_{2} \mathrm{SO}_{4}$ ), with acid consumption as low as $3.2-5.3 \mathrm{~mol} \mathrm{H}^{+} / \mathrm{mol} \mathrm{P}$ and up to $90 \% \mathrm{P}$ recovery. Particularly, the consumption when recovering P from MBM (3.2-4.2 mol $\mathrm{H}^{+} / \mathrm{mol} \mathrm{P}$ ) is close to that required for P recovery from natural phosphate rock.

\section{Acknowledgment}

The research was financially supported by the British Council (Newton Fund) and the China Scholarship Council [File No. 201503780024]. The authors wish to thank Dr. Judith Zhou for helping with the IC analysis, Catherine Unsworth for running the ICP-OES analysis, and Dr. Shi Shi for carrying out the XRD analysis. We also gratefully acknowledge the biomass fuel plants, who chose to be anonymous, for providing the ash samples.

\section{References}

Adams, P.W., Hammond, G.P., McManus, M.C., Mezzullo, W.G., 2011. Barriers to and drivers for UK bioenergy development. Renew. Sustain. Energy Rev. 15, 1217-1227. doi:10.1016/j.rser.2010.09.039

Akinola, O., 2013. Overview of Phosphorus Recovery and Recycling From Selected Waste Streams - Protecting Phosphorus as a Resource. Imperial College London. Azuara, M., Kersten, S.R.A., Kootstra, A.M.J., 2013. Recycling phosphorus by fast pyrolysis of pig manure: Concentration and extraction of phosphorus combined with formation of value-added pyrolysis products. Biomass Bioenerg. 49, 171180. doi:10.1016/j.biombioe.2012.12.010

Bogush, A.A., Stegemann, J.A., Williams, R., Wood, I.G., 2018. Element speciation in UK biomass power plant residues based on composition, mineralogy, microstructure and leaching. Fuel 211, 712-725. doi:10.1016/j.fuel.2017.09.103 
Bolan, N.S., Szogi, A.A., Chuasavathi, T., Seshadri, B., Rothrock, M.J., Panneerselvam, P., 2010. Uses and management of poultry litter. Worlds. Poult. Sci. J. 66, 673-698. doi:10.1017/S0043933910000656

Brod, E., Øgaard, A.F., Hansen, E., Wragg, D., Haraldsen, T.K., Krogstad, T., 2015. Waste products as alternative phosphorus fertilisers part I: inorganic $\mathrm{P}$ species affect fertilisation effects depending on soil $\mathrm{pH}$. Nutr. Cycl. Agroecosystems 103, 167-185. doi:10.1007/s10705-015-9734-1

Cela, S., Berenguer, P., Santiveri, F., Lloveras, J., 2010. Potential phosphorus, potassium, and magnesium surpluses in an irrigated maize monoculture fertilized with Pig slurry. Agron. J. 102, 96-102. doi:10.2134/agronj2009.0139

Chow, L.C., 2001. Solubility of Calcium Phosphates. Octacalcium Phosphate 1, 94111. doi:10.1159/000061650

Cohen, Y., 2009. Phosphorus dissolution from ash of incinerated sewage sludge and animal carcasses using sulphuric acid. Environ. Technol. 30, 1215-1226. doi:10.1080/09593330903213879

Cooper, J., 2014. Managing phosphorus in the UK water industry to increase national resource security. The University of Birmingham.

Cooper, J., Carliell-Marquet, C., 2013. A substance flow analysis of phosphorus in the UK food production and consumption system. Resour. Conserv. Recycl. 74, 82100. doi:10.1016/j.resconrec.2013.03.001

Cordell, D., 2010. The story of phosphorus: Sustainability implications of global phosphorus scarcity for food security. Linköping University.

Cordell, D., Drangert, J.O., White, S., 2009. The story of phosphorus: Global food security and food for thought. Glob. Environ. Chang. doi:10.1016/j.gloenvcha.2008.10.009

Cordell, D., Rosemarin, A., Schroder, J.J., Smit, A.L., 2011. Towards global phosphorus security: A systems framework for phosphorus recovery and reuse options. Chemosphere 84, 747-758. doi:10.1016/j.chemosphere.2011.02.032

Coutand, M., Cyr, M., Deydier, E., Guilet, R., Clastres, P., 2008. Characteristics of industrial and laboratory meat and bone meal ashes and their potential applications. J. Hazard. Mater. 150, 522-532. doi:10.1016/j.jhazmat.2007.04.133

Delvasto, P., Valverde, A., Ballester, A., Igual, J.M., Munoz, J.A., Gonzalez, F., Blazquez, M.L., Garcia, C., 2006. Characterization of brushite as a recrystallization product formed during bacterial solubilization of hydroxyapatite in batch cultures. Soil Biol. Biochem. 38, 2645-2654. doi:10.1016/j.soilbio.2006.03.020

Demirbas, A., 2004. Combustion characteristics of different biomass fuels. Prog. Energy Combust. Sci. 30, 219-230. doi:10.1016/j.pecs.2003.10.004

Desmidt, E., Ghyselbrecht, K., Zhang, Y., Pinoy, L., Van der Bruggen, B., Verstraete, W., Rabaey, K., Meesschaert, B., 2015. Global Phosphorus Scarcity and FullScale P-Recovery Techniques: A Review. Crit. Rev. Environ. Sci. Technol. 45, 336-384. doi:10.1080/10643389.2013.866531

Deydier, E., Guilet, R., Sharrock, P., 2003. Beneficial use of meat and bone meal combustion residue: "An efficient low cost material to remove lead from aqueous effluent.” J. Hazard. Mater. 101, 55-64. doi:10.1016/S03043894(03)00137-7

Dorozhkin, S. V, 2012. Dissolution mechanism of calcium apatites in acids: A review of literature. World J. Methodol. 2, 1-17. doi:10.5662/wjm.v2.i1.1

Dorozhkin, S. V, 1997. Surface Reactions of Apatite Dissolution. J. Colloid Interface Sci. 191, 489-497. doi:10.1006/jcis.1997.4942 
Dorozhkin, S. V, 1996. Fundamentals of the Wet-Process Phosphoric Acid Production . 1 . Kinetics and Mechanism of the Phosphate Rock Dissolution. Ind. Eng. Chem. Res. 35, 4328-4335. doi:10.1021/ie960092u

Ekpo, U., Ross, A.B., Camargo-Valero, M.A., Fletcher, L.A., 2016. Influence of pH on hydrothermal treatment of swine manure: Impact on extraction of nitrogen and phosphorus in process water. Bioresour. Technol. 214, 637-644.

Elouear, Z., Bouzid, J., Boujelben, N., Feki, M., Jamoussi, F., Montiel, A., 2008. Heavy metal removal from aqueous solutions by activated phosphate rock. J. Hazard. Mater. 156, 412-420. doi:10.1016/j.jhazmat.2007.12.036

Elser, J., Bennett, E., 2011. A broken biogeochemical cycle. Nature 478, $29-31$. doi:10.1038/478029a

Elliott, J. C., 2002. Calcium Phosphate Biominerals. Rev. Mineral. Geochem. 48(1): 427-453.

Fleet, M. E., 2009. Infrared spectra of carbonate apatites: v2-Region bands. Biomaterials 30(8): 1473-1481.

Franke, R., Hormes, J., 1995. The P K-near edge absorption spectra of phosphates. Phys. B Phys. Condens. Matter 216, 85-95. doi:10.1016/0921-4526(95)00446-7

Grzmil, B., Wronkowski, J., 2006. Removal of phosphates and fluorides from industrial wastewater. Desalination 189, 261-268. doi:10.1016/j.desal.2005.07.008

Gunkel-Grillon, P., Roth, E., Laporte-Magoni, C., Le Mestre, M., 2015. Effects of long term raw pig slurry inputs on nutrient and metal contamination of tropical volcanogenic soils, Uvéa Island (South Pacific). Sci. Total Environ. 533, 339-46. doi:10.1016/j.scitotenv.2015.06.110

Harouaka, K., Eisenhauer, A., Fantle, M.S., 2014. Experimental investigation of Ca isotopic fractionation during abiotic gypsum precipitation. Geochim. Cosmochim. Acta 129, 157-176. doi:10.1016/j.gca.2013.12.004

Havukainen, J., Nguyen, M.T., Hermann, L., Horttanainen, M., Mikkilä, M., Deviatkin, I., Linnanen, L., 2016. Potential of phosphorus recovery from sewage sludge and manure ash by thermochemical treatment. Waste Manag. 49, 221229. doi:10.1016/j.wasman.2016.01.020

He, Z., Pagliari, P.H., Waldrip, H.M., 2016. Applied and Environmental Chemistry of Animal Manure: A Review. Pedosphere 26, 779-816. doi:10.1016/S10020160(15)60087-X

Heilmann, S.M., Molde, J.S., Timler, J.G., Wood, B.M., Mikula, A.L., Vozhdayev, G. V, Colosky, E.C., Spokas, K. a, Valentas, K.J., 2014. Phosphorus Reclamation through Hydrothermal Carbonization of Animal Manures. Environ. Sci. Technol. doi:10.1021/es501872k

Huang, H., Yuan, X., 2015. Recent progress in the direct liquefaction of typical biomass. Prog. Energy Combust. Sci. 49, 59-80. doi:10.1016/j.pecs.2015.01.003

IFDC, 2010. World Phosphate Rock Reserves and Resources. International Fertilizer Development Centre.

Ingall, E. D., Brandes J. A., Diaz J. M., de Jonge M. D., Paterson D., McNulty I., Elliott W.C., Northrup P., 2011. Phosphorus K-edge XANES spectroscopy of mineral standards. J. Synchrotron Radiat 18: 189-197.

Johnsson, M.S.-A., Nancollas, G.H., 1992. The Role of Brushite and Octacalcium Phosphate in Apatite Formation. Crit. Rev. Oral Biol. Med. 3, 61-82. doi:10.1177/10454411920030010601

Kaikake, K., Sekito, T., Dote, Y., 2009. Phosphate recovery from phosphorus-rich solution obtained from chicken manure incineration ash. Waste Manag. 29, 
1084-1088. doi:10.1016/j.wasman.2008.09.008

Kleemann, R., Chenoweth, J., Clift, R., Morse, S., Pearce, P., Saroj, D., 2015. Evaluation of local and national effects of recovering phosphorus at wastewater treatment plants: Lessons learned from the UK. Resour. Conserv. Recycl. 105, 347-359. doi:10.1016/j.resconrec.2015.09.007

Komiyama, T., Kobayashi, A., Yahagi, M., 2013. The chemical characteristics of ashes from cattle, swine and poultry manure. J. Mater. Cycles Waste Manag. 15, 106-110. doi:10.1007/s10163-012-0089-2

Kongsomart, B., Kannari, N., Takarada, T., 2016. Catalytic Effects of BiomassDerived Ash on Loy Yang Brown Coal Gasification. Int. J. Biomass Renewables $5,12-22$.

Kuligowski, K., Poulsen, T.G., 2010. Phosphorus and zinc dissolution from thermally gasified piggery waste ash using sulphuric acid. Bioresour. Technol. 101, 51235130. doi:10.1016/j.biortech.2010.01.143

Kuz'mina, M.A., Zhuravlev, S. V., Frank-Kamenetskaya, O. V., 2013. The effect of medium chemistry on the solubility and morphology of brushite crystals. Geol. Ore Depos. 55, 692-697. doi:10.1134/S1075701513080072

Leng, L., Li, J., Wen, Z., Zhou, W., 2018a. Use of microalgae to recycle nutrients in aqueous phase derived from hydrothermal liquefaction process. Bioresour. Technol. 256, 529-542. doi:10.1016/j.biortech.2018.01.121

Leng, L., Li, J., Yuan, X., Li, J., Han, P., Hong, Y., Wei, F., Zhou, W., $2018 b$. Beneficial synergistic effect on bio-oil production from co-liquefaction of sewage sludge and lignocellulosic biomass. Bioresour. Technol. 251, 49-56. doi:10.1016/j.biortech.2017.12.018

Leng, L., Yuan, X., Huang, H., Jiang, H., Chen, X., Zeng, G., 2014. The migration and transformation behavior of heavy metals during the liquefaction process of sewage sludge. Bioresour. Technol. 167, 144-150. doi:10.1016/j.biortech.2014.05.119

Leng, L., Yuan, X., Shao, J., Huang, H., Wang, H., Li, H., Chen, X., Zeng, G., 2016. Study on demetalization of sewage sludge by sequential extraction before liquefaction for the production of cleaner bio-oil and bio-char. Bioresour. Technol. 200, 320-327. doi:10.1016/j.biortech.2015.10.040

Magalhães, M.C.F., Williams, P.A., 2007. Apatite Group Minerals Solubility and Environmental Remediation, in: Thermodynamics, Solubility and Environmental Issues. pp. 327-340.

Mayer, B.K., Baker, L.A., Boyer, T.H., Drechsel, P., Gifford, M., Hanjra, M.A., Parameswaran, P., Stoltzfus, J., Westerhoff, P., Rittmann, B.E., 2016. Total Value of Phosphorus Recovery. Environ. Sci. Technol. 50, 6606-6620. doi:10.1021/acs.est.6b01239

Murphy, J., Riley, J.P., 1962. A modified single solution method for the determination of phosphate in natural waters. Anal. Chim. Acta 27, 31-36. doi:10.1016/S00032670(00)88444-5

Niu, Y., Tan, H., Hui, S., 2016. Ash-related issues during biomass combustion: Alkali-induced slagging, silicate melt-induced slagging (ash fusion), agglomeration, corrosion, ash utilization, and related countermeasures. Prog. Energy Combust. Sci. 52, 1-61. doi:10.1016/j.pecs.2015.09.003

Olsen, S.R., Cole, C. V, Watandbe, F., Dean, L., 1954. Estimation of Available Phosphorus in Soil by Extraction with sodium Bicarbonate. U.S. Dep. Agric. 939.

Olson, B.M., Bremer, E., McKenzie, R.H., Bennett, R., 2010. Phosphorus 
accumulation and leaching in two irrigated soils with incremental rates of cattle manure. Can. J. Soil Sci. 90, 355-362. doi:10.4141/CJSS09025

Oshita, K., Sun, X., Kawaguchi, K., Shiota, K., Takaoka, M., Matsukawa, K., Fujiwara, T., 2016. Aqueous leaching of cattle manure incineration ash to produce a phosphate enriched fertilizer. J. Mater. Cycles Waste Manag. 18, 608617. doi:10.1007/s10163-016-0528-6

Oxmann, J. F., 2014. Technical Note: An X-ray absorption method for the identification of calcium phosphate species using peak-height ratios. Biogeosciences 11(8): 2169-2183.

Parhi, P., Ramanan, A., Ray, A.R., 2006. Hydrothermal Synthesis of nanocrystalline powders of alkaline-earth hydroxyapatites, A10(PO4)6(OH)2 $(\mathrm{A}=\mathrm{Ca}, \mathrm{Sr}$ and Ba). J. Mater. Sci. 41, 1455-1458. doi:10.1007/s10853-006-7460-4

Pettersson, A., Åmand, L.-E., Steenari, B.-M., 2008a. Leaching of ashes from cocombustion of sewage sludge and wood-Part II: The mobility of metals during phosphorus extraction. Biomass Bioenerg. 32, 236-244. doi:10.1016/j.biombioe.2007.09.006

Pettersson, A., Åmand, L.-E., Steenari, B.-M., 2008b. Leaching of ashes from cocombustion of sewage sludge and wood-Part I: Recovery of phosphorus. Biomass Bioenerg. 32, 224-235. doi:10.1016/j.biombioe.2007.09.016

Peters, F., Schwarz K., Epple M., 2000. The structure of bone studied with synchrotron X-ray diffraction, X-ray absorption spectroscopy and thermal analysis. Thermochim. Acta 361(1-2): 131-138.

Petzet, S., Peplinski, B., Cornel, P., 2012. On wet chemical phosphorus recovery from sewage sludge ash by acidic or alkaline leaching and an optimized combination of both. Water Res. 46, 3769-3780. doi:10.1016/j.watres.2012.03.068

Ragauskas, A.J., 2006. The Path Forward for Biofuels and Biomaterials. Science. 311, 484-489. doi:10.1126/science.1114736

Rajendran, J., Gialanella S., Aswath P. B., 2013. XANES analysis of dried and calcined bones. Mat. Sci. Eng. C-Mater. 33(7): 3968-3979.

Ravel, B., Newville M., 2005. ATHENA, ARTEMIS, HEPHAESTUS: data analysis for X-ray absorption spectroscopy using IFEFFIT. J. Synchrotron Radiat. 12: 537-541.

Rittmann, B.E., Mayer, B., Westerhoff, P., Edwards, M., 2011. Capturing the lost phosphorus. Chemosphere 84, 846-853. doi:10.1016/j.chemosphere.2011.02.001

Saidur, R., Abdelaziz, E.A., Demirbas, A., Hossain, M.S., Mekhilef, S., 2011. A review on biomass as a fuel for boilers. Renew. Sustain. Energy Rev. 15, 22622289. doi:10.1016/j.rser.2011.02.015

Sattari, S.Z., Bouwman, A.F., Giller, K.E., van Ittersum, M.K., 2012. Residual soil phosphorus as the missing piece in the global phosphorus crisis puzzle. Proc. Natl. Acad. Sci. U. S. A. 109, 6348-53. doi:10.1073/pnas.1113675109

Simons, A., Solomon, D., Chibssa, W., Blalock, G., Lehmann, J., 2014. Filling the phosphorus fertilizer gap in developing countries. Nat. Geosci. 7, 3-3. doi:10.1038/ngeo2049

Stegemann, J.A., Côté, P.L., 1991. Acid Neutralization Capacity, Appendix B: Investigation of test methods for solidified waste evaluation-a cooperative program, Manuscript Series TS-15, Environment Canada Wastewater Technology Centre, Burlington, Ontario Canada.

Štulajterová, R., Medvecký, L', 2008. Effect of calcium ions on transformation brushite to hydroxyapatite in aqueous solutions. Colloids Surfaces A Physicochem. Eng. Asp. 316, 104-109. doi:10.1016/j.colsurfa.2007.08.036 
Sugiyama, S., Kitora, R., Kinoshita, H., Nakagawa, K., Katoh, M., Nakasaki, K., 2016. Recovery of Calcium Phosphates from Composted Chicken Manure. J. Chem. Eng. Japan 49, 224-228. doi:10.1252/jcej.15we111

Szögi, A.A., Vanotti, M.B., Hunt, P.G., 2015. Phosphorus recovery from pig manure solids prior to land application. J. Environ. Manage. 157, 1-7.

Tan, Z., Lagerkvist, A., 2011. Phosphorus recovery from the biomass ash: A review. Renew. Sustain. Energy Rev. 15, 3588-3602. doi:10.1016/j.rser.2011.05.016

Tayibi, H., Choura, M., López, F.A., Alguacil, F.J., López-Delgado, A., 2009. Environmental impact and management of phosphogypsum. J. Environ. Manage. 90, 2377-2386. doi:10.1016/j.jenvman.2009.03.007

Tilman, D., Fargione, J., Wolff, B., D’Antonio, C., Dobson, A., Howarth, R., Schindler, D., Schlesinger, W.H., Simberloff, D., Swackhamer, D., 2001. Forecasting agriculturally driven global environmental change. Science 292, 281-284. doi:10.1126/science. 1057544

Tilman, D., Lehman, C., 1987. Human-caused environmental change : Impacts on plant diversity and evolution. Proc. Natl. Acad. Sci. U. S. A. 98, 5433-5440. doi:10.1073/pnas.091093198

United States Geological Survey, 2019. Phosphate Rock, Mineral Commodity Summaries, p. 122-123. Available from: https://prd-wret.s3-us-west2.amazonaws.com/assets/palladium/production/atoms/files/mcs-2019-phosp.pdf [accessed 17/6/19].

Vassilev, S. V., Baxter, D., Andersen, L.K., Vassileva, C.G., 2013a. An overview of the composition and application of biomass ash. Part 2. Potential utilisation, technological and ecological advantages and challenges Fuel 105, 19-39. doi:10.1016/j.fuel.2012.10.001

Vassilev, S. V., Baxter, D., Andersen, L.K., Vassileva, C.G., 2013b. An overview of the composition and application of biomass ash. Part 1. Phase-mineral and chemical composition and classification. Fuel 105, 40-76. doi:10.1016/j.fuel.2012.09.041

Vassilev, S. V., Baxter, D., Andersen, L.K., Vassileva, C.G., Morgan, T.J., 2012. An overview of the organic and inorganic phase composition of biomass. Fuel 94, 133. doi:10.1016/j.fuel.2011.09.030

Vassilev, S. V., Baxter, D., Vassileva, C.G., 2013c. An overview of the behaviour of biomass during combustion: Part I. Phase-mineral transformations of organic and inorganic matter. Fuel 112, 391-449. doi:10.1016/j.fuel.2013.05.043

Wilfert, P., Kumar, P.S., Korving, L., Witkamp, G.J., Van Loosdrecht, M.C.M., 2015. The Relevance of Phosphorus and Iron Chemistry to the Recovery of Phosphorus from Wastewater: A Review. Environ. Sci. Technol. 49, 9400-9414. doi:10.1021/acs.est.5b00150

Williams, A.G., Leinonen, I., Kyriazakis, I., 2016. Environmental benefits of using turkey litter as a fuel instead of a fertiliser. J. Clean. Prod. 113, 167-175. doi:10.1016/j.jclepro.2015.11.044

Wu, S., Wang, L., Zhao, L., Zhang, P., El-shall, H., 2018. Recovery of rare earth elements from phosphate rock by hydrometallurgical processes - A critical review. Chem. Eng. J. 335, 774-800. doi:10.1016/j.cej.2017.10.143

Zhang, F.S., Yamasaki, S., Kimura, K., 2002. Waste ashes for use in agricultural production: II. Contents of minor and trace metals. Sci. Total Environ. 286, 111118. doi:10.1016/S0048-9697(01)00968-8 


\section{Figure captions}

Fig. 1 X-ray powder diffraction (XRD) (a), Fourier transform infrared spectra (FTIR, normalised) (b), Thermogravimetric (TG/DTG) (c), and P K-edge X-ray absorption near edge structure (XANES, normalised) (d) analyses of meat and bone meal (MBM) bottom ashes (BA) and air pollution control residue (APCr), and poultry litter co-combustion (PL) bottom ash and residues from leaching of the same residues at $\mathrm{pH}$ 5.1-6.8. The reference materials Morrocan apatite (carbonate apatite), brushite, and apatite (hydroxyapatite) were all analyzed by FTIR, TG/DTG, and XANES, but only the references most relevant to each figure were presented; XRD references were from the XRD pattern database (International Centre for Diffraction Data, ICDD).

Fig. 2 Concentration of available $\mathrm{P}$ in meat and bone meal (MBM) bottom ashes (BA) and air pollution control residue (APCr), and poultry litter co-combustion (PL) bottom ash and residues from leaching of the same residues at pH 5.1-6.8. Error bars represent the standard deviation of three replicates.

Fig. 3 Anion leaching from meat and bone meal (MBM) bottom ashes (BA) and air pollution control residue (APCr), and poultry litter co-combustion (PL) bottom ash in the Acid Neutralization Capacity test (circled points are those for which the leached residue was characterised).

Fig. 4 Major element leaching from meat and bone meal (MBM) bottom ashes (BA) and air pollution control residue (APCr), and poultry litter co-combustion (PL) bottom ash in the Acid Neutralization Capacity test (circled points are those for which the leached residue was characterised). 
Fig. 5 P recovery (average of duplicates) from meat and bone meal (MBM) bottom ashes (BA) and air pollution control residue (APCr), and poultry litter cocombustion (PL) bottom ash using $\mathrm{H}_{2} \mathrm{SO}_{4}$ and $\mathrm{HNO}_{3}$, (a) Acid consumption comparison between $\mathrm{H}_{2} \mathrm{SO}_{4}$ and $\mathrm{HNO}_{3}$; (b) P recovery percentage using $\mathrm{H}_{2} \mathrm{SO}_{4}$. Leaching time $2 \mathrm{~h}$; Solid/liquid ratio 0.1 . 


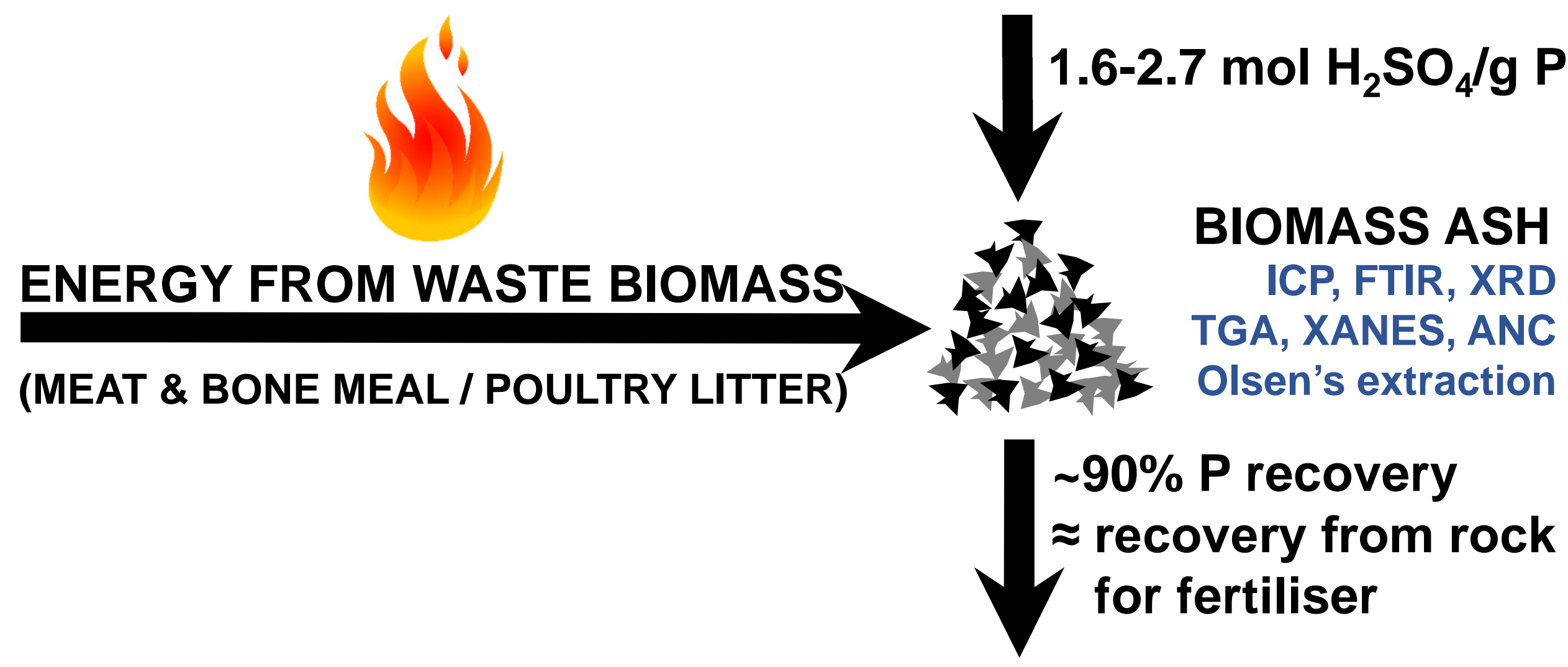




\title{
Characterisation of ashes from waste biomass power plants and phosphorus recovery
}

\author{
Lijian Leng, Anna A. Bogush, Amitava Roy, Julia A. Stegemann*
}

\section{Highlights}

- Meat and bone meal (MBM) and poultry litter (PL) biomass ashes were characterised

- $\mathrm{P}$ is mainly $\mathrm{Ca}_{5}\left(\mathrm{PO}_{4}\right)_{3}(\mathrm{OH})$ in $\mathrm{MBM}$ ashes and $\mathrm{KNaCa}_{2}\left(\mathrm{PO}_{4}\right)_{2}$ in $\mathrm{PL}$ ashes

- P recovery by acid dissolution seems feasible and promising

- Optimized acid consumption for $\sim 90 \% \mathrm{P}$ recovery is as low as $3.2-5.3 \mathrm{~mol} \mathrm{H}^{+} / \mathrm{mol} \mathrm{P}$ 


\section{Characterisation of ashes from waste biomass power plants and phosphorus recovery}

Lijian Leng ${ }^{\text {a }}$, Anna A. Bogush ${ }^{\text {b }}$, Amitava Roy ${ }^{c}$, Julia A. Stegemann ${ }^{\text {b }}$ 5

${ }^{\text {a }}$ School of Resources, Environmental \& Chemical Engineering and Key Laboratory

of Poyang Lake Environment and Resource Utilization, Ministry of Education,

Nanchang University, Nanchang, 330031, China

${ }^{\mathrm{b}}$ Centre for Resource Efficiency \& the Environment, Department of Civil,

Environmental \& Geomatic Engineering, University College London, Chadwick

Building, Gower Street, London WC1E 6BT, UK

${ }^{\mathrm{c}}$ J. Bennett Johnston, Sr., Center for Advanced Microstructures \& Devices, Louisiana

State University, 6980 Jefferson Hwy, Baton Rouge, LA 70806, USA

* Corresponding author. Tel.: +44(0)2076797370

E-mail address: j.stegemann@ucl.ac.uk(J.A. Stegemann) 
Abstract: Biowastes, such as meat and bone meal (MBM), and poultry litter (PL), are used as energy sources for industrial combustion in the UK. However, the biomass ashes remaining after combustion, which contain nutrients such as phosphorus, are landfilled rather than utilised. To promote their utilisation, biomass ashes from industries were characterised in terms of their elemental and mineral compositions, phosphorus extractability, and $\mathrm{pH}$-dependent leachability. These ashes were highly alkaline ( $\mathrm{pH}$ as high as 13), and rich in calcium and phosphorus. The $\mathrm{P}$ bioavailabilities in the ash evaluated by Olsen's extraction were low. Hydroxyapatite and potassium sodium calcium phosphate were identified by X-ray powder diffraction (XRD) as the major phases in the MBM and PL ashes, respectively. The leaching of $\mathrm{P}$, $\mathrm{Ca}$, and many other elements was $\mathrm{pH}$ dependent, with considerable increase in leaching below about $\mathrm{pH}$ 6. P recovery by acid dissolution (e.g., with $\mathrm{H}_{2} \mathrm{SO}_{4}$ ) seems feasible and promising; the optimized acid consumption for $\sim 90 \%$ P recovery could be as low as 3.2-5.3 $\mathrm{mol} \mathrm{H}^{+} / \mathrm{mol} \mathrm{P}$.

Keywords: incineration; fertiliser; phosphorus recovery; acid neutralisation capacity; animal manure 


\section{Introduction}

Thermal or biological processing of biomass produces heat, electricity, or liquid/gas/solid bioenergy with low net greenhouse gas emissions (Ragauskas, 2006). Wood and wood wastes, agricultural crops and their waste byproducts, animal wastes, wastes from food processing, aquatic plants, and algae are the most widely used biomass energy resources (Bogush et al., 2018; Demirbas, 2004; Huang and Yuan, 2015; Leng et al., 2018a, 2018b, 2016; Saidur et al., 2011). These biomass resources, which are currently often treated as organic wastes, can contribute significantly to the generation of renewable energy and reduction of greenhouse gas (GHG) emissions, reducing the dependency on fossil fuels (Ragauskas, 2006). The UK, for example, sets a target of $80 \%$ GHG emissions reduction over 1990 levels by 2050; the bioenergy industry contributes significantly to the achievement of these goals (Adams et al., 2011).

Consequently, recovery of energy from biomass by combustion or production of fuel, e.g., from straw, meat and bone meal, poultry litter, wood shavings, and horse bedding, is increasing in the UK, due to the mounting production of these wastes, their energy contents, and the environmental benefits of their utilisation (Oshita et al., 2016; Williams et al., 2016). However, management of ash has emerged to be one of the problems impeding the development of biomass combustion for energy (Niu et al., 2016). Since biomass ashes are rich in the nutrients phosphorus and potassium, they have been considered for use as a soil amendment on agricultural land. However, the low $\mathrm{P}$ availability, high alkalinity (e.g., $\mathrm{pH} 13$ or higher), and heavy metal contents in these ashes may restrict their direct application (Niu et al., 2016; Vassilev et al., 2013a; Bogush et al., 2018). Environmental pollution from nutrient and contaminant leaching can occur, and result in negative effects on crops, soils and water, when 
ashes are applied under soil and climatic conditions that increase environmental mobility of contaminants (Pettersson et al., 2008a; 2008b), or mobilise nutrients but do not favour their agronomic utilization, e.g., due to excessive application or an imbalance in the nutrient proportions (Bolan et al., 2010; Codling et al., 2002; Szögi et al., 2015; Williams et al., 2016). However, it is worth mentioning that environmental pollution by nutrients and contaminants has also been observed for soil fertilized with animal residues (e.g., pig slurry) directly (Cela et al., 2010; GunkelGrillon et al., 2015; Olson et al., 2010).

Meanwhile, the widespread global use of $\mathrm{P}$ fertiliser over the past century and increasing demand for $\mathrm{P}$ by agriculture threatens to deplete sources of P-bearing rock within the next century (Cordell et al., 2009; 2010; Mayer et al., 2016; Sattari et al., 2012; Tilman et al., 2001; Tilman and Lehman, 1987). Even ignoring rapidly increasing $\mathrm{P}$ demand, the estimated static lifetime of phosphorus reserves is only around 350 years (IFDC, 2010). Furthermore, the remaining reserves are highly geographically concentrated (Elser and Bennett, 2011), with around $71 \%$ located in Morocco and the Western Sahara (USGS, 2019). Therefore, sourcing $\mathrm{P}$ from the $\mathrm{P}$ consumption lifecycle and developing appropriate $\mathrm{P}$ recovery technology, especially in places with a scarcity of natural P-bearing rock such as the UK, is important to meet the increasing demand for this element (Cooper, 2014; Cordell et al., 2011; Mayer et al., 2016; Rittmann et al., 2011). Phosphorus recovery from animal residues (e.g., poultry litter, meat and bone meal) and sewage sludge, and their incineration ashes, is one of the most promising ways to increase the $\mathrm{P}$ resource security and secure future food production (Akinola, 2013; Bogush et al., 2018; Havukainen et al., 2016; Kleemann et al., 2015; Mayer et al., 2016; Tan and Lagerkvist, 2011). Cooper and Carliell-Marquet (2013) estimated that the P recovery potential from animal 
manure produced in the UK could be higher than national net total $\mathrm{P}$ imports; in general, the $\mathrm{P}$ value of meat and bone meal/animal bone alone is likely of a similar order of magnitude to that of a country's phosphate fertiliser imports (Cooper and Carliell-Marquet, 2013; Simons et al., 2014).

Hence, recovery of $\mathrm{P}$ from biomass ashes to produce more effective and environmentally benign $\mathrm{P}$ fertilizer is of increasing interest for both research and practice. Animal manures and manure derivatives such as ash and char have been widely explored for P recovery, with measurement of varied recovery rates and acid demands because of differences between the sources (e.g., P concentration 4.0-139 g $\mathrm{kg}^{-1}$ ) and process conditions (e.g., different acid types and loads, and solid/liquid ratios) (Table 1). For example, $\mathrm{P}$ recovery rates around $90 \%$ were obtained for animal manure char, but at acid loads in the region of $100 \mathrm{~mol} \mathrm{H}^{+} / \mathrm{mol} \mathrm{P}$ recovered (Azuara et al., 2013; Heilmann et al., 2014). Lower acid loads (3-10 mol H $\mathrm{H}^{+} / \mathrm{mol} \mathrm{P}$ recovered) were found effective for P recovery from manures and their ashes (Cohen, 2009; Kaikake et al., 2009; Kuligowski and Poulsen, 2010), which is similar to the recovery rates and acid loads for P recovery from sewage sludge ash (Petzet et al., 2012). In addition to $\mathrm{P}$ content and recovery conditions, $\mathrm{P}$ speciation in the different $\mathrm{P}$ containing resources (wastes) also influences $\mathrm{P}$ recovery performance. Elemental, mineral and chemical compositions have been used to describe $\mathrm{P}$ speciation in these materials (Bogush et al., 2018; Vassilev et al., 2013a, 2013b, 2013c), but few studies have related these results to $\mathrm{P}$ recovery performance. Furthermore, little has been reported regarding meat and bone meal (MBM) and its derivatives (e.g., ash), despite the high $\mathrm{P}$ recovery potential from these materials.

The main objectives of this research were thus:

1) to characterise biomass ashes from combustion of MBM or co-combustion of 
poultry litter (PL) in UK biomass power plants (https://biofuelwatch.org.uk/wpcontent/maps/uk-biomass.html), and

2) to examine the potential and options for P recovery from these biomass ashes.

The bioavailability of $\mathrm{P}$ from biomass ashes and potential for its recovery from the biomass ashes depends on $\mathrm{P}$ speciation and matrix composition. The biomass ashes were therefore characterised by multiple techniques, including elemental analysis, thermogravimetric analysis (TGA), determination of crystalline phases by X-ray powder diffraction (XRD), characterization of functional groups by Fourier transform infrared spectroscopy (FTIR), and measurement of acid neutralization capacity (ANC) and $\mathrm{pH}$-dependent $\mathrm{P}$ leachability, to understand the mechanisms responsible for control of P solubility. P K-edge X-ray absorption near edge spectroscopy (XANES) was used to examine the speciation of $\mathrm{P}$ in complex matrices without interference from irrelevant phases and irrespective of crystallinity.

\section{Materials and methods}

\subsection{Materials}

Five samples of biomass ash were collected from four different industrial-scale biomass power plants in the UK that use different biomass types as the energy source. The plants use moving grate incinerators with a combustion temperature of $850{ }^{\circ} \mathrm{C}$, dry discharge of bottom ash, and dry scrubbing of the flue gas. MBM1-BA and MBM2-BA were bottom ashes collected from two different plants that combust MBM; MBM2-APCr was the fly ash from the second plant. PL1-BA and PL2-BA were both bottom ashes from different power plants that co-combust PL. The moisture contents of the biomass ashes were negligible (Bogush et al., 2018). The samples were ground to $<250 \mu \mathrm{m}$ using a ball mill and then stored in air-tight containers before use.

$$
\text { Reference materials used in the mineralogical investigation included a Ward's }
$$


Science Apatite Research Mineral (www.wardsci.com; Catalogue No. 470026-560), a Moroccan apatite (carbonate apatite), and brushite $\left(\mathrm{CaHPO}_{4} \cdot 2 \mathrm{H}_{2} \mathrm{O}, 99.0 \%\right.$, SigmaAldrich).

\subsection{Biomass ash elemental composition and bioavailability of $P$}

The biomass ashes were subjected to total digestion using $\mathrm{HNO}_{3}: \mathrm{HClO}_{4}: \mathrm{H}_{2} \mathrm{O}_{2}(\mathrm{v}$, $30 \%)=5: 5: 3, \mathrm{v} / \mathrm{v})($ Leng et al., 2014) before chemical analysis for the elements of interest (Section 2.7). Separate extracts for P analysis (Section 2.7) were prepared by digestion with potassium persulfate at $150^{\circ} \mathrm{C}$ for $4.0 \mathrm{~h}$.

Olsen's method has been widely used to evaluate the bioavailability of phosphorus (Olsen et al., 1954). The extraction was conducted in for all of the biomass samples and residues from leaching at mildly acidic $\mathrm{pH}$ (Section 2.5) by mixing $2.5 \mathrm{~g}$ ash with $50 \mathrm{~mL} 0.5 \mathrm{M}$ of sodium bicarbonate $(\mathrm{pH} 8.5)$ and shaking for $30 \mathrm{~min}$ before separation of the extracts for analysis (Section 2.7).

\subsection{Biomass ash mineralogy}

The crystalline phases present in the biomass ashes and residues after leaching at mildly acidic $\mathrm{pH}$ (Section 2.5) were identified by XRD analysis on an XPERT-PRO diffractometer with an X-ray source of $\mathrm{Cu} \mathrm{K}_{\alpha}$ radiation at $40 \mathrm{KV}$ and $30 \mathrm{~mA}$. A scanning speed of $4 \mathrm{~s}$ per step and step size of $0.05^{\circ}(2 \theta)$ were used in the scanning range of $5^{\circ}-70^{\circ}(2 \theta)$. The XRD data were analysed by using Jade software version 6.0 (Materials Data Inc., Livermore, USA).

Fourier transform infrared spectra (FTIR) of the biomass ashes, residues, and reference materials were obtained on a Thermo-Fischer Scientific Nicolet 670 spectrometer in the wavelength range of $400-4000 \mathrm{~cm}^{-1}$.

Thermogravimetric analysis of the biomass ashes, residues, and reference materials was conducted by heating from room temperature to $1000{ }^{\circ} \mathrm{C}$ at a rate of $10{ }^{\circ} \mathrm{C} / \mathrm{min}$ 
under nitrogen atmosphere.

\subsection{Phosphorus speciation}

The speciation of $\mathrm{P}$ in the biomass ashes and residues after leaching at mild acidic $\mathrm{pH}$ (Section 2.5) was assessed by comparing their P K-edge X-ray absorption near edge structure (XANES) spectra with those of the reference materials. P K-edge measurements were made at the Low Energy X-ray Absorption Spectroscopy (Lexas) beamline of Louisiana State University's synchrotron research facility, the J. Bennett Johnston, Sr. Center for Advanced Microstructures and Devices (CAMD), USA. Lexas is a windowless beamline, i.e., with only a $13 \mu \mathrm{m}$ think Katon ${ }^{\mathrm{TM}}$ window separating the ring from the experimental chamber. A University of Bonn-designed Lemonnier type monochromator with InSb 111 crystals was used in measurements. The measurements were made in fluorescence by diluting the sample as necessary with boron nitride to reduce self-absorption (Oxmann, 2014). A Ketek $150 \mathrm{~mm}^{2}$ silicon drift detector was used for fluorescence measurements. The white line of reagent grade aluminum phosphate was used to calibrate the monochromator at $2152.8 \mathrm{eV}$. The parameters for the measurements were $2050 \mathrm{eV}$ to $2110 \mathrm{eV}$ with $5 \mathrm{eV}$ steps, $2110 \mathrm{eV}$ to $2142 \mathrm{eV}$ with $0.5 \mathrm{eV}$ steps, $2142 \mathrm{eV}$ to $2160 \mathrm{eV}$ with $0.1 \mathrm{eV}$ steps, from 2160 to $2180 \mathrm{eV}$ with $0.5 \mathrm{eV}$ steps, and $2180 \mathrm{eV}$ to $2250 \mathrm{eV}$ with $1 \mathrm{eV}$ steps. The integration time was from 1 to 5 seconds for adequate counting statistics. The spectra were analyzed with Athena in Demeter (Ravel and Newville, 2005).

\section{5 pH-dependent leaching}

The acid neutralization capacity (ANC) of the biomass ashes was measured to examine their $\mathrm{pH}$ responses to acid addition, and the consequent changes in the solubilities of their components of interest. This test involves adding increasing amounts of nitric acid to a series of 10 or more subsamples of the material under 
investigation (Stegemann and Côté, 1991). A single series of $5.0 \mathrm{~g}$ subsamples was weighed out for each of the biomass ashes and mixed with $30 \mathrm{~mL}$ of nitric acid diluted with deionized water to a concentration from 0 to $3 \mathrm{~N}$ (up to $18 \mathrm{meq} / \mathrm{g}$ of biomass ash) $\mathrm{HNO}_{3}$. After $48 \mathrm{~h}$ of end-over-end mixing at $30 \mathrm{rpm}$, the samples were centrifuged, and the $\mathrm{pH}$ values and conductivities of all the supernatants were measured before separation of the leachates for analysis. The solid residues corresponding to leachates with mild acidic $\mathrm{pH}(6.2,5.1,5.9,6.5$, and 6.8 for MBM1BA, MBM2-BA, MBM2-APCr, PL1-BA, and PL2-BA, respectively (Table S1) were also analysed by XRD (Section 2.3) FTIR (Section 2.3), XANES (Section 2.4), and Olsen's method (Section 2.2) after drying at $60{ }^{\circ} \mathrm{C}$.

\subsection{Acid extraction for phosphorus recovery}

To further assess acid extractability of $\mathrm{P}$ from the biomass ashes, the effects of contact time $(0-48 \mathrm{~h})$, liquid/solid ratio $\left(4-20 \mathrm{~mL} / \mathrm{g}\right.$ of ash), acid type $\left(\mathrm{HNO}_{3}\right.$ and $\left.\mathrm{H}_{2} \mathrm{SO}_{4}\right)$, and acid load (6-16 meq $\mathrm{H}^{+} / \mathrm{g}$ ash) were investigated with the volume of the extraction liquid fixed at $30 \mathrm{~mL}$. Experiments were conducted in duplicate. $\mathrm{P}$ recovery rate was defined as the percentage of $\mathrm{P}$ in the leachate as compared with that in the original ash.

\subsection{Chemical analysis of extracts and leachates}

Liquid samples from digestion, extraction, and wastewater treatment were filtered from the solids through $0.45 \mu \mathrm{m}$ membrane filters; leachates for metal analysis were acidified to $\mathrm{pH} 2$ before storage.

$\mathrm{P}$ in the filtered liquid samples was determined by colorimetry at $880 \mathrm{~nm}$, by reaction with ammonium molybdate using ascorbic acid as the reducing agent (Murphy and Riley, 1962).

Metals, including Al, B, Bi, Ba, Ca, Co, Cr, Cu, Cd, Fe, K, Mg, Li, Mn, Na, Ni, Pb, 
$\mathrm{Sr}$, and $\mathrm{Zn}$, and $\mathrm{P}$ in the extracts from total digestion of the biomass ashes and the ANC test leachates were determined by Inductively Coupled Plasma Optical Emission Spectroscopy (ICP-OES).

Anions in the ANC leachates, including $\mathrm{F}, \mathrm{Cl}^{-}, \mathrm{Br}^{-}, \mathrm{NO}_{2}{ }^{-}, \mathrm{NO}_{3}{ }^{-}, \mathrm{PO}_{4}{ }^{3-}$ and $\mathrm{SO}_{4}{ }^{2-}$, were analysed by a Dionex AQUION Ion Chromatography (IC) before acidification of the samples.

All chemical analyses were conducted in triplicate with reporting of mean values.

\section{Results and discussion}

\subsection{Biomass ash elemental composition and bioavailability of $P$}

The elemental compositions of the biomass ashes in Table 2 are typical for ashes from animal residue incineration (Bogush et al., 2018; Oshita et al., 2016; Vassilev et al., 2012; Zhang et al., 2002). Apart from P, the major elements are Al, Fe, K, Mg, $\mathrm{Mn}$, and $\mathrm{Na}$, with $\mathrm{Ca}$ as the most abundant element comprising $16-32 \%$ of the total ash.

The $\mathrm{P}$ concentrations of these ashes range from $8.3-13 \%$, which is comparable to that of some natural phosphorus rocks [e.g., 30-40\% $\mathrm{P}_{2} \mathrm{O}_{5} ; 13-17.5 \% \mathrm{P}$ (Desmidt et al., 2015; Elouear et al., 2008)]. However, Fig. 2 shows that the contents of bioavailable $\mathrm{P}$ in the ashes are less than $800 \mathrm{mg} \mathrm{P} / \mathrm{kg}$ ash, corresponding to $<0.7 \%$ of the total P.

The contents of $\mathrm{K}$ and, especially, $\mathrm{Mg}$, in the PL ashes are higher than those of the MBM ashes. Some differences between the compositions of ashes from different MBM incineration plants can also be observed, e.g., MBM1-BA has higher contents of $\mathrm{Ca}$ and $\mathrm{P}$, and lower contents of $\mathrm{K}$ and Na compared to MBM2-BA, showing the effects of variations in the original MBM materials. Minor elements such as B, Zn, Sr, $\mathrm{Ba}$, and $\mathrm{Cu}$ are in the range of $100-1100 \mathrm{mg} / \mathrm{kg}$, while trace elements such as $\mathrm{Bi}, \mathrm{Cd}$, 
$\mathrm{Cr}, \mathrm{Co}, \mathrm{Li}, \mathrm{Ni}$, and $\mathrm{Pb}$ are $<100 \mathrm{mg} / \mathrm{kg}$.

\subsection{Biomass ash mineralogy}

Fig. 1(a) shows that the dominant phase identified in the MBM ashes by XRD is hydroxyapatite (HAP), which is consistent with the high contents of $\mathrm{Ca}$ and $\mathrm{P}$. Hydroxyapatite, with some carbonation, is the principal mineral in bone (e.g., Elliott, 2002), and increases in crystallinity with heating. Both $\beta$-tricalcium phosphate $[\beta-$ $\left.\mathrm{Ca}_{3}\left(\mathrm{PO}_{4}\right)_{2}, \beta-\mathrm{TCP}\right]$ and HAP were identified by XRD as the major phases in either dried or calcined bones (Brod et al., 2015; Rajendran et al., 2013). XRD identified potassium sodium calcium phosphate $\left[\mathrm{KNaCa}_{2}\left(\mathrm{PO}_{4}\right)_{2}\right]$ as the main phase in the PL ashes. This phase is also identified as the major mineral phase after combustion of $\mathrm{P}$ and Ca-bearing biomass at a temperature of $815{ }^{\circ} \mathrm{C}$ (Kongsomart et al., 2016). The solubility of apatite varies significantly depending on its content of other anions (e.g., $\mathrm{CO}_{3}{ }^{2-}, \mathrm{Cl}^{-}$or $\mathrm{F}^{-}$) (Magalhães and Williams, 2007), but $\mathrm{Ca}_{5}\left(\mathrm{PO}_{4}\right)_{3}(\mathrm{OH})$, which has $\mathrm{K}_{\mathrm{sp}}$ $=3.98 \times 10^{-59}$ (Chow, 2001; Delvasto et al., 2006) might be expected to have low bioavailability, as was observed for the biomass ashes (Section 3.1). No data about bioavailability was found for $\mathrm{KNaCa}_{2}\left(\mathrm{PO}_{4}\right)_{2}$.

A comparison of the Moroccan apatite FTIR spectrum with those of the ashes [Fig. 1(b)] shows that all are dominated by the ca. $1030 \mathrm{~cm}^{-1}$ (anti-symmetric stretch $\Upsilon_{3}$ ) band, with the $\Upsilon_{1}$ (ca. $\left.960 \mathrm{~cm}^{-1}\right)$ and symmetric stretch $\Upsilon_{4}$ bands $\left(\mathrm{F}_{2}\right.$ bend 650$525 \mathrm{~cm}^{-1}$ ) also being conspicuous; the resemblance to the reference material is most obvious for MBM1-BA and MBM2-APCr. However, all phosphate bands show some shift, indicating variations in composition, e.g., substitution of $\mathrm{CO}_{3}{ }^{2-}$ in the crystal structure. The $\mathrm{CO}_{3}{ }^{2-}$ ion can be found in the channels (A type) of the hexagonal crystal structure of apatite, or substitutes for the phosphate ion (B type). With B type carbonate apatite, there is a doublet around $1430 \mathrm{~cm}^{-1}$ (Fleet, 2009), as seen in the 
Moroccan apatite. PL1-BA thus seems to contain carbonate apatite whereas the other ashes showed only hydroxyapatite. The $\mathrm{OH}^{-}$peak at $3420 \mathrm{~cm}^{-1}$ in all FTIR spectra is quite weak, but the derivative thermogravimetric (DTG) curves [Fig. 1(c)] show that all ashes have mass loss peaks in the region $200{ }^{\circ} \mathrm{C}$ to $400{ }^{\circ} \mathrm{C}$. A comparison with apatite standards used in this study (not shown) and data from the literature suggests this peak is from the $\mathrm{OH}$ in the apatite in the ashes. The DTG curves also have doublets, which vary in strength depending on the biomass ash, in the region $600^{\circ} \mathrm{C}$ to $800^{\circ} \mathrm{C}$, one of which is likely from the carbonate in the apatite structure, whereas the other one is calcium carbonate (Peters et al., 2000).

Previous studies have also found hydroxyapatite and $\mathrm{KNaCa}_{2}\left(\mathrm{PO}_{4}\right)_{2}$ (Bogush et al., 2018; Coutand et al., 2008; Komiyama et al., 2013; Oshita et al., 2016; Sugiyama et al., 2016), but also other minerals, e.g., $\mathrm{Ca}_{3}\left(\mathrm{PO}_{4}\right)_{2}$ in ashes from MBM or animal manure combustion (Coutand et al., 2008; Sugiyama et al., 2016) and $\mathrm{Ca}_{9} \mathrm{MgK}\left(\mathrm{PO}_{4}\right)_{7}$ in manure ashes (Komiyama et al., 2013; Oshita et al., 2016).

XRD also showed portlandite $\left[\mathrm{Ca}(\mathrm{OH})_{2}\right]$ in the MBM ashes, which is corroborated by the $3643 \mathrm{~cm}^{-1}$ FTIR band, suggestive of $\mathrm{OH}^{-}$in $\mathrm{Ca}(\mathrm{OH})_{2}$ for all ashes but PL1-BA. The single similar carbonate band around $1430 \mathrm{~cm}^{-1}\left(\Upsilon_{3}\right)$ in the FTIR spectra of all ashes except PL1-BA is typical of calcite, corresponding to calcite $\left(\mathrm{CaCO}_{3}\right)$ peaks in the XRD patterns except PL ashes.

$\mathrm{XRD}$ indicates sulphate to be present as calcium sulphate $\left(\mathrm{CaSO}_{4}\right)$ in all $\mathrm{MBM}$ ashes (Table 3), and arcanite $\left(\mathrm{K}_{2} \mathrm{SO}_{4}\right)$ in the MBM2 and PL ashes. The FTIR spectra of MBM2-BA and PL2-BA are unlike those of the other ashes due to higher amounts of arcanite, which presents as peaks at $618 \mathrm{~cm}^{-1}, 1100 \mathrm{~cm}^{-1}$ and $1197 \mathrm{~cm}^{-1}$. Sulfate breakdown may be responsible for the peak observed in the DTG at $931^{\circ} \mathrm{C}(\mathrm{MBM} 2-$ APCr). 
XRD also shows quartz $\left(\mathrm{SiO}_{2}\right)$ in the PL ashes and MBM1-BA, and abundant halite $(\mathrm{NaCl})$ in $\mathrm{MBM} 2-\mathrm{APCr}$ and MBM2-BA.

\subsection{Phosphorus speciation}

Fig. 1(d) shows the phosphorus K-edge XANES spectra of the samples along with that of the Ward's Science apatite. The white line position (A) of the latter is $2151.84 \mathrm{eV}$, while that of the ash samples ranges from $2151.67 \mathrm{eV}$ to $2151.85 \mathrm{eV}$. The phosphate white line is from resonance between $1 \mathrm{~s}$ and higher energy $t_{2} *$ orbitals, while the peak around $2168 \mathrm{eV}$ is from the P-O bond. The location and intensity of the $\mathrm{C}$ and $\mathrm{D}$ maxima depend on the composition and crystallinity of the phosphate phases (Ingall et al., 2011). These ashes thus have different phosphate compositions. Linear combination fitting of the spectrum of the MBM1-BA ash shows it to be principally composed of apatite, but the fit of apatite was not as good for the other ashes. The inflection of the shoulder at $\sim 2155 \mathrm{eV}$ correlates with the $\mathrm{Ca} / \mathrm{P}$ ratio of the structure (Franke and Hormes, 1995); consequently, the PL ashes, which are indicated by $\mathrm{XRD}$ to contain $\mathrm{KNaCa}_{2}\left(\mathrm{PO}_{4}\right)_{2}$, appear to have a lower $\mathrm{Ca} / \mathrm{P}$ ratio than the $\mathrm{MBM}$ ashes, in which $\mathrm{Ca}_{5}\left(\mathrm{PO}_{4}\right)_{3}(\mathrm{OH})$ was identified as the main P-bearing mineral.

There are some contradictions when comparing mineralogy results obtained from different analytical techniques. The variance between mineralogical analyses can be expected when applying different techniques to very small samples, particularly for complex materials such as these. Mineral phases identified by XRD were used in the following discussions unless specified otherwise.

\section{$3.4 \mathrm{pH}$ dependent leaching and characterisation of the leached residues}

The leachate $\mathrm{pH}$ values resulting from the discrete acid loading (on the secondary ordinate in Figs. 3 and 4) suggest a small, near vertical, plateau corresponding to neutralisation of the abundant $\mathrm{Ca}(\mathrm{OH})_{2}$ in the $\mathrm{MBM}$ ash at $\mathrm{pH} \sim 12$; this plateau is 
absent for the PL ashes, which contain little $\mathrm{Ca}(\mathrm{OH})_{2}$ (section 3.2).

A second $\mathrm{pH}$ plateau at $\sim 7$ may be attributable to several different phenomena. Dissolution of the small component of calcite in the ashes, which will yield a $\mathrm{pH}$ lower than that of 8.3 expected in equilibrium with the atmosphere since the leaching tubes are sealed, likely contributes to this plateau. For the MBM ashes, the plateau also reflects dissolution of $\mathrm{Ca}_{5}\left(\mathrm{PO}_{4}\right)_{3}(\mathrm{OH})$, which has an equilibrium $\mathrm{pH}$ of $\sim 7.5$ (based on the $\mathrm{K}_{\mathrm{sp}}$ noted above). Perhaps most importantly, a phosphate buffer system will result from dissolution of the apatite, and, especially, $\mathrm{KNaCa}_{2}\left(\mathrm{PO}_{4}\right)_{2}$. The second plateau is more apparent for the PL ashes, which had an acid neutralization capacity of 9-10 meq $\mathrm{H}^{+} / \mathrm{g}$ to $\mathrm{pH} 4$, whereas it was only $5-6 \mathrm{H}^{+}$meq/g for the MBM ashes. There is a third $\mathrm{pH}$ plateau, below $\mathrm{pH} 4$.

Fig. 3 shows that sulfate, released at high $\mathrm{pH}$ by dissolution of $\mathrm{K}_{2} \mathrm{SO}_{4}$, drops in concentration below $\mathrm{pH} 8$, likely due to precipitation of gypsum $\left(\mathrm{CaSO}_{4} \cdot 2 \mathrm{H}_{2} \mathrm{O} ; \mathrm{K}_{\mathrm{sp}}=\right.$ $2.62 \times 10^{-5}$; Harouaka et al., 2014), as Ca enters solution from calcite and the phosphate minerals (Fig. 4). Since there is little $\mathrm{K}_{2} \mathrm{SO}_{4}$ to dissolve from MBM1-BA, $\mathrm{Ca}$ is not precipitated and its leached concentration is therefore higher than for the other ashes.

Fig. 3 shows constant concentrations of chloride regardless of $\mathrm{pH}$ for each biomass ash, consistent with the presence of $\mathrm{NaCl}$ identified by XRD. $\mathrm{Na}$ and $\mathrm{K}$ are also initially released from $\mathrm{NaCl}$ and $\mathrm{K}_{2} \mathrm{SO}_{4}$, but their concentrations rise slightly as the $\mathrm{pH}$ falls in the MBM ash leachates, and increase dramatically below $\mathrm{pH} 8$ in the PL ash leachates. P (Fig. 4, and phosphate, Fig. 3) concentrations are seen to be low above $\mathrm{pH} \sim 4$, and then increase as the phosphate minerals dissolve with further acid addition. Release of $\mathrm{Na}$ and $\mathrm{K}$ with $\mathrm{P}$ from dissolution of the $\mathrm{KNaCa}_{2}\left(\mathrm{PO}_{4}\right)_{2}$ in the $\mathrm{PL}$ ashes would be expected, but the increases in their concentrations before the 
concentration of $\mathrm{P}$ starts to rise suggest that the dissolution of $\mathrm{KNaCa}_{2}\left(\mathrm{PO}_{4}\right)_{2}$ is incongruent, with selective loss of $\mathrm{K}$ and $\mathrm{Na}$, or that this mineral dissolves and reprecipitates, e.g., as brushite $\left(\mathrm{CaHPO}_{4} \cdot 2 \mathrm{H}_{2} \mathrm{O}\right)$ (Johnsson and Nancollas, 1992).

$\mathrm{Mg}, \mathrm{Ba}$ and $\mathrm{Sr}$ (Fig. S1) seem to be mainly released in association with the $\mathrm{pH} \sim 7$ plateau. They may substitute for $\mathrm{Ca}$ in calcite or phosphate minerals and are released when those dissolve. $\mathrm{Cu}$ and $\mathrm{Zn}$ form phosphates of low solubility and are mainly released below $\mathrm{pH} 4$; the leaching rates of these elements were undetectable or at very low level at pH 8-12 from MBM1-BA (Fig. S1), because of the relatively low total contents of minor elements in this ash (Table 2). The concentrations of Fe were almost undetectable, and those of $\mathrm{Al}$ were negligible, in the leachates from the $\mathrm{MBM}$ ashes and PL2-BA. Iron oxides have low solubility, and it is possible that $\mathrm{Fe}_{3}\left(\mathrm{PO}_{4}\right)_{2} \cdot 8 \mathrm{H}_{2} \mathrm{O} / \mathrm{FePO}_{4}, \mathrm{AlPO}_{4}, \mathrm{~Pb}_{5}\left(\mathrm{PO}_{4}\right)_{3}(\mathrm{OH}) / \mathrm{Pb}_{3}\left(\mathrm{PO}_{4}\right)_{2}$, and $\mathrm{Zn}_{3}\left(\mathrm{PO}_{4}\right)_{2}$, which have low solubility, may exist in the original ashes or were formed as secondary precipitates during the test (Deydier et al., 2003; Parhi et al., 2006; Wilfert et al., 2015).

XRD of the residues in Fig. 1(a) from leaching at mildly acidic pH (5.1-6.8; Section 2.5) shows precipitation of $\mathrm{CaHPO}_{4} \cdot 2 \mathrm{H}_{2} \mathrm{O}\left[\mathrm{K}_{\mathrm{sp}}=2.57 \times 10^{-7}\right.$; (Chow, 2001)], which forms under acidic conditions (Johnsson and Nancollas, 1992). Dorozhkin's dissolution mechanism for hydroxyapatite (Eqs. 1-3) demonstrates that $\mathrm{Ca}_{5}\left(\mathrm{PO}_{4}\right)_{3}(\mathrm{OH})$ would produce $\mathrm{Ca}_{3}\left(\mathrm{PO}_{4}\right)_{2}\left(\mathrm{~K}_{\mathrm{sp}}=3.16 \times 10^{-26}\right.$ for $\alpha-\mathrm{Ca}_{3}\left(\mathrm{PO}_{4}\right)_{2}$ and $\mathrm{K}_{\mathrm{sp}}$ $=1.26 \times 10^{-29}$ for $\left.\beta-\mathrm{Ca}_{3}\left(\mathrm{PO}_{4}\right)_{2}(\mathrm{Chow}, 2001)\right)$ at the first stage and then addition of additional acid would yield metastable $\mathrm{CaHPO}_{4}$, and finally the dissolution of $\mathrm{CaHPO}_{4}$ (Dorozhkin, 2012; 1997). Brushite solubility can markedly rise with a decrease in $\mathrm{pH}$ from 6 to 3 (Kuz'mina et al., 2013) and at lower $\mathrm{pH}$ it dissolves linearly (Figs. 3 and 4). 
$2 \mathrm{Ca}_{5}\left(\mathrm{PO}_{4}\right)_{3}(\mathrm{OH})+2 \mathrm{H}^{+} \rightarrow 3 \mathrm{Ca}_{3}\left(\mathrm{PO}_{4}\right)_{2}+\mathrm{Ca}^{2+}+2 \mathrm{H}_{2} \mathrm{O}$

$\mathrm{Ca}_{3}\left(\mathrm{PO}_{4}\right)_{2}+2 \mathrm{H}^{+} \rightarrow 2 \mathrm{CaHPO}_{4}+\mathrm{Ca}^{2+}$

$\mathrm{CaHPO}_{4}+\mathrm{H}^{+} \rightarrow \mathrm{H}_{2} \mathrm{PO}_{4}^{-}+\mathrm{Ca}^{2+}$

The presence of $\mathrm{CaHPO}_{4} \cdot 2 \mathrm{H}_{2} \mathrm{O}$ in the residues after leaching at mildly acidic $\mathrm{pH}$ (pH 5.1-6.8) was verified by multiple techniques. Fig. 1(a) shows that it dominates the XRD patterns of the leached residues, while the peak intensities for $\mathrm{Ca}_{5}\left(\mathrm{PO}_{4}\right)_{3}(\mathrm{OH})$ in MBM ashes are reduced and $\mathrm{KNaCa}_{2}\left(\mathrm{PO}_{4}\right)_{2}$ in $\mathrm{PL}$ ashes have almost disappeared. The prominent peak around $1650 \mathrm{~cm}^{-1}$ found in the FTIR spectra of all the leached residues as seen in [Fig. 1 (b)] corresponds to the molecular $\mathrm{H}_{2} \mathrm{O}$ peak from $\mathrm{CaHPO}_{4} \cdot 2 \mathrm{H}_{2} \mathrm{O}$ at $1645.48 \mathrm{~cm}^{-1}$. The precipitation of $\mathrm{CaHPO}_{4} \cdot 2 \mathrm{H}_{2} \mathrm{O}$ is also evident in the DTG traces for the leached residues of all the ashes as a peak at $\sim 183^{\circ} \mathrm{C}$ [Fig. 1 (c)], with the amount ranging from 21.6-24.2\%. Finally, the P K-edge XANES spectra [Fig. 1(d)] confirm that different phosphate phases are present in the leached residues than the original ashes, although fitting to estimate the exact $\mathrm{P}$ composition is difficult as several phosphate phases are present. Although $\mathrm{CaHPO}_{4} \cdot 2 \mathrm{H}_{2} \mathrm{O}\left(\mathrm{K}_{\mathrm{sp}}=2.57 \times 10^{-7}\right)$ in the residues is more soluble than $\mathrm{Ca}_{5}\left(\mathrm{PO}_{4}\right)_{3}(\mathrm{OH})\left(\mathrm{K}_{\mathrm{sp}}=3.98 \times 10^{-59}\right)$, the bioavailable $\mathrm{P}$ in the solid residues separated from the mildly acidic leachates remained low at $<1400 \mathrm{mg} \mathrm{P} / \mathrm{kg}$ ash (Fig. 2). It is noteworthy that $\mathrm{CaHPO}_{4} \cdot 2 \mathrm{H}_{2} \mathrm{O}$ can transform back to $\mathrm{Ca}_{5}\left(\mathrm{PO}_{4}\right)_{3}(\mathrm{OH})$ or $\mathrm{Ca}_{3}\left(\mathrm{PO}_{4}\right)_{2}$ in an alkaline and calcium-rich environment (Štulajterová and Medvecký, 2008).

During leaching, the water-soluble $\mathrm{NaCl}, \mathrm{K}_{2} \mathrm{SO}_{4}$, and acid-soluble calcite and $\mathrm{Ca}(\mathrm{OH})_{2}$ were not found in the leached residues, as shown in Fig. 1(a), but gypsum $\left(\mathrm{CaSO}_{4} \cdot 2 \mathrm{H}_{2} \mathrm{O}\right)$ and $\mathrm{SiO}_{2}$ remained, as they are acid-insensitive over the $\mathrm{pH}$ range studied. The absence of the $618 \mathrm{~cm}^{-1}$ and $1195 \mathrm{~cm}^{-1}$ bands in the FTIR spectra of the leached residues [Fig. 1(b)] indicate the dissolution of the sulfate phases. The $713 \mathrm{~cm}^{-}$ 
${ }^{1}$ carbonate band from calcite is very weak to non-existent in the residues [Fig. 1(b)]. In the thermogravimetric analysis of the leached residues, all the mass loss occurred by $600^{\circ} \mathrm{C}$, and the absence of a calcite peak [Fig. 1(c)] reflect complete dissolution of calcite at the lower $\mathrm{pH}$.

To summarize, $\mathrm{NaCl}$ and $\mathrm{K}_{2} \mathrm{SO}_{4}$ present in ashes dissolved readily with water leaching. Other chemical components dissolved with decreasing $\mathrm{pH}$ or increasing acid addition. Alkaline $\mathrm{CaCO}_{3}$ and $\mathrm{Ca}(\mathrm{OH})_{2}$ were neutralized at the first plateau and followed by the dissolution of $\mathrm{Ca}_{5}\left(\mathrm{PO}_{4}\right)_{3}(\mathrm{OH})$ and $\mathrm{KNaCa}_{2}\left(\mathrm{PO}_{4}\right)_{2}$ to produce $\mathrm{CaHPO}_{4} \cdot 2 \mathrm{H}_{2} \mathrm{O}$ at $\mathrm{pH} \sim 7$, which continued to dissolve with releasing of $\mathrm{P}$ to the leachate from $\mathrm{pH} \sim 4 . \mathrm{Mg}, \mathrm{Ba}$ and $\mathrm{Sr}$ mainly released in association with the $\mathrm{pH} \sim 7$ plateau while the release of $\mathrm{Fe}, \mathrm{Al}, \mathrm{Zn}$, and $\mathrm{Cu}$ became evident at $\mathrm{pH} 4$.

\subsection{Phosphorus recovery from biomass ash}

$\mathrm{P}$ release in the ANC test can be used to estimate the $\mathrm{P}$ recovery potential from the biomass ashes studied. Phosphorus recovery was found to be linearly dependent on the leachate $\mathrm{pH}$ below $\mathrm{pH} 4$, attaining $40-50 \%$ at $\mathrm{pH} 3$, and $\sim 100 \%$ P recovery at $\mathrm{pH} \sim 1$ [Fig. S2(a)]. Determination of the acid consumption per unit of $\mathrm{P}$ recovered [Fig. S2(b)] is essential to assess the economic feasibility of the recovery process, and ranged from 9-14 meq $\mathrm{H}^{+} / \mathrm{g}$ ash, assuming that the other ashes follow the trend established to $100 \%$ recovery for PL1-BA.

Investigation of the contact time showed that $\mathrm{P}$ recovery reached $75-95 \%$ of its highest value within several minutes [Fig. S3(a)], but the $\mathrm{pH}$ needed several hours to reach steady state [Fig. S3(b)]. This implies that $\mathrm{P}$ could be recovered promptly before surplus acid is consumed by the solid ash residue.

Solid/liquid (S/L) ratio also plays a significant role in P recovery; less acid was consumed per unit of $\mathrm{P}$ recovered at lower $\mathrm{S} / \mathrm{L}$ ratios because of more efficient mixing 
411 (Fig. S4). For example, results show that $10-20 \%$ less acid will be needed at S/L ratio of 0.05 , than at a $\mathrm{S} / \mathrm{L}$ of 0.1 , which is the ratio that has been widely used for $\mathrm{P}$ dissolution from biomass ashes (Oshita et al., 2016; Sugiyama et al., 2016). Unfortunately, a lower S/L ratio also produces a larger amount of leachate with a lower $\mathrm{P}$ concentration, which could make the recycling of $\mathrm{P}$ and the subsequent wastewater treatment much more difficult.

$\mathrm{HNO}_{3}$ and $\mathrm{H}_{2} \mathrm{SO}_{4}$ were therefore applied at $\mathrm{S} / \mathrm{L} 0.1$, with a contact time of $2 \mathrm{~h}$, to assess the influence of the acid type on $\mathrm{P}$ recovery and acid consumption. $\mathrm{H}_{2} \mathrm{SO}_{4}$ seems to be more efficient for P leaching from these biomass ashes compared with $\mathrm{HNO}_{3}$ particularly at lower acid load (Fig. 5). During the $\mathrm{H}_{2} \mathrm{SO}_{4}$ process, the precipitation of gypsum promotes the dissolution of apatite, and facilitates the separation of the product. By comparison, separation of dissolved $\mathrm{Ca}\left(\mathrm{NO}_{3}\right)_{2}$ formed during $\mathrm{HNO}_{3}$ leaching is difficult. At $\mathrm{H}_{2} \mathrm{SO}_{4}$ load of $14 \mathrm{meq} \mathrm{H}^{+} / \mathrm{g}$ ash, the acid consumption is in the range of $3.2-5.3 \mathrm{~mol} \mathrm{H}^{+} / \mathrm{mol} \mathrm{P}$ (Fig. 5), which is comparable with those reported in previous studies when animal manures or their derivatives (e.g., ashes) (Table 1) or sewage sludge ashes (Petzet et al., 2012) were used for P recovery. Meanwhile, P recovery of $\sim 90 \%$ or higher was achieved at this acid load.

\subsection{Economic considerations}

In the phosphorus industry, phosphoric acid is the basic starting raw material for production, which is normally produced from phosphate rock. The wet process is the most commonly used phosphoric acid production process, in which $\mathrm{H}_{2} \mathrm{SO}_{4}$ dissolves $\mathrm{Ca}_{5}\left(\mathrm{PO}_{4}\right)_{3}(\mathrm{~F}, \mathrm{Cl}, \mathrm{OH})$, followed with purification and condensation to produce phosphoric acid $\left(\mathrm{H}_{3} \mathrm{PO}_{4}\right)$ and byproduct phosphogypsum (Tayibi et al., 2009). $\mathrm{Ca}_{5}\left(\mathrm{PO}_{4}\right)_{3} \mathrm{~F}$ is the dominant component of natural phosphate rock and its dissolution mechanisms during wet-process phosphoric acid production can be described by Eqs. 
4-7 (Dorozhkin, 1996), which are similar to those for $\mathrm{Ca}_{5}\left(\mathrm{PO}_{4}\right)_{3}(\mathrm{OH})($ Eqs. 1-3). The overall reaction can be described by Eq. 8 (Wu et al., 2018).

$$
2 \mathrm{Ca}_{5}\left(\mathrm{PO}_{4}\right)_{3}(\mathrm{~F}, \mathrm{OH})+2 \mathrm{H}^{+} \rightarrow 3 \mathrm{Ca}_{3}\left(\mathrm{PO}_{4}\right)_{2}+\mathrm{Ca}^{2+}+2 \mathrm{HF}, \mathrm{H}_{2} \mathrm{O}
$$

$$
\mathrm{Ca}_{3}\left(\mathrm{PO}_{4}\right)_{2}+2 \mathrm{H}^{+} \rightarrow 2 \mathrm{CaHPO}_{4}+\mathrm{Ca}^{2+}
$$

$\mathrm{CaHPO}_{4}+\mathrm{H}^{+} \rightarrow \mathrm{H}_{2} \mathrm{PO}_{4}^{-}+\mathrm{Ca}^{2+}$

$\mathrm{H}_{2} \mathrm{PO}_{4}^{-}+\mathrm{H}^{+} \rightarrow \mathrm{H}_{3} \mathrm{PO}_{4}$

$\mathrm{Ca}_{10}\left(\mathrm{PO}_{4}\right)_{6}(\mathrm{~F}, \mathrm{OH})_{2}+10 \mathrm{H}_{2} \mathrm{SO}_{4}+\mathrm{nH}_{2} \mathrm{O} \rightarrow 10 \mathrm{CaSO}_{4} \cdot \mathrm{nH}_{2} \mathrm{O}+6 \mathrm{H}_{3} \mathrm{PO}_{4}+2 \mathrm{HF}, \mathrm{H}_{2} \mathrm{O}$

The theoretical acid consumption for the wet-process phosphoric acid production is $3.3 \mathrm{~mol} \mathrm{H} / \mathrm{mol} \mathrm{P}$ or $1.67 \mathrm{~mol} \mathrm{H}_{2} \mathrm{SO}_{4} / \mathrm{mol} \mathrm{H}_{3} \mathrm{PO}_{4}$. If the final product is $\mathrm{H}_{2} \mathrm{PO}_{4}{ }^{-}$, the consumption drops to $2.3 \mathrm{~mol} \mathrm{H} \mathrm{H}^{+} / \mathrm{mol} \mathrm{P}$, which is the lowest acid addition needed to dissolve all P into the aqueous phase. However, the processes described by Eqs. 6 and 7 proceed at the same time; thus, the lowest theoretical acid consumption for $\mathrm{P}$ dissolution from $\mathrm{Ca}_{5}\left(\mathrm{PO}_{4}\right)_{3}(\mathrm{~F}, \mathrm{OH})$ would be 2.3-3.3 mol H $\mathrm{H}^{+} / \mathrm{mol} \mathrm{P}$. Considering the presence of minerals such as $\mathrm{CaCO}_{3}, \mathrm{MgCO}_{3}, \mathrm{CaO}$, and $\mathrm{MgO}$ in natural phosphate rock, the consumption would be $>2.3-3.3 \mathrm{~mol} \mathrm{H} / \mathrm{mol} \mathrm{P}$ depending on the content of acid-consuming components, which is comparable to that of dissolution of MBM ashes (3.2-4.2 $\mathrm{mol} \mathrm{H} \mathrm{H}^{+} / \mathrm{mol} \mathrm{P)}$. Furthermore, the dissolution of MBM ashes (composed of $\left.\mathrm{Ca}_{5}\left(\mathrm{PO}_{4}\right)_{3}(\mathrm{OH})\right)$ would not be complicated by the presence of fluorine, which is abundant in phosphate rock. Therefore, $\mathrm{P}$ recovery from MBM ashes by direct acid dissolution seems very promising and worth further investigation.

\section{Conclusions}

Hydroxyapatite $\left[\mathrm{Ca}_{5}\left(\mathrm{PO}_{4}\right)_{3}(\mathrm{OH})\right]$ and potassium sodium calcium phosphate $\left[\mathrm{KNaCa}_{2}\left(\mathrm{PO}_{4}\right)_{2}\right]$ seem to be the main mineral phases in the MBM and PL ashes, respectively, with low bioavailability of $\mathrm{P}$. Phosphate leaching is $\mathrm{pH}$ dependent and 
significant recovery was experienced at $\mathrm{pH}<4$. Major heavy metals such as $\mathrm{Cu}$ and Zn demonstrated similar leaching behavior as $\mathrm{P}$. A substantial proportion of the $\mathrm{P}$ remaining in the solid residues after acid leaching was transformed to brushite, but its bioavailability increased only slightly.

It appears that secondary $\mathrm{P}$, for industrial production of fertilizer or other chemicals, could be recovered from MBM and PL ashes by acid dissolution (particularly by $\mathrm{H}_{2} \mathrm{SO}_{4}$ ), with acid consumption as low as $3.2-5.3 \mathrm{~mol} \mathrm{H}^{+} / \mathrm{mol} \mathrm{P}$ and up to $90 \% \mathrm{P}$ recovery. Particularly, the consumption when recovering P from MBM (3.2-4.2 mol $\mathrm{H}^{+} / \mathrm{mol} \mathrm{P}$ ) is close to that required for P recovery from natural phosphate rock.

\section{Acknowledgment}

The research was financially supported by the British Council (Newton Fund) and the China Scholarship Council [File No. 201503780024]. The authors wish to thank Dr. Judith Zhou for helping with the IC analysis, Catherine Unsworth for running the ICP-OES analysis, and Dr. Shi Shi for carrying out the XRD analysis. We also gratefully acknowledge the biomass fuel plants, who chose to be anonymous, for providing the ash samples.

\section{References}

Adams, P.W., Hammond, G.P., McManus, M.C., Mezzullo, W.G., 2011. Barriers to and drivers for UK bioenergy development. Renew. Sustain. Energy Rev. 15, 1217-1227. doi:10.1016/j.rser.2010.09.039

Akinola, O., 2013. Overview of Phosphorus Recovery and Recycling From Selected Waste Streams - Protecting Phosphorus as a Resource. Imperial College London. Azuara, M., Kersten, S.R.A., Kootstra, A.M.J., 2013. Recycling phosphorus by fast pyrolysis of pig manure: Concentration and extraction of phosphorus combined with formation of value-added pyrolysis products. Biomass Bioenerg. 49, 171180. doi:10.1016/j.biombioe.2012.12.010

Bogush, A.A., Stegemann, J.A., Williams, R., Wood, I.G., 2018. Element speciation in UK biomass power plant residues based on composition, mineralogy, microstructure and leaching. Fuel 211, 712-725. doi:10.1016/j.fuel.2017.09.103 
Bolan, N.S., Szogi, A.A., Chuasavathi, T., Seshadri, B., Rothrock, M.J., Panneerselvam, P., 2010. Uses and management of poultry litter. Worlds. Poult. Sci. J. 66, 673-698. doi:10.1017/S0043933910000656

Brod, E., Øgaard, A.F., Hansen, E., Wragg, D., Haraldsen, T.K., Krogstad, T., 2015. Waste products as alternative phosphorus fertilisers part I: inorganic $\mathrm{P}$ species affect fertilisation effects depending on soil $\mathrm{pH}$. Nutr. Cycl. Agroecosystems 103, 167-185. doi:10.1007/s10705-015-9734-1

Cela, S., Berenguer, P., Santiveri, F., Lloveras, J., 2010. Potential phosphorus, potassium, and magnesium surpluses in an irrigated maize monoculture fertilized with Pig slurry. Agron. J. 102, 96-102. doi:10.2134/agronj2009.0139

Chow, L.C., 2001. Solubility of Calcium Phosphates. Octacalcium Phosphate 1, 94111. doi:10.1159/000061650

Cohen, Y., 2009. Phosphorus dissolution from ash of incinerated sewage sludge and animal carcasses using sulphuric acid. Environ. Technol. 30, 1215-1226. doi:10.1080/09593330903213879

Cooper, J., 2014. Managing phosphorus in the UK water industry to increase national resource security. The University of Birmingham.

Cooper, J., Carliell-Marquet, C., 2013. A substance flow analysis of phosphorus in the UK food production and consumption system. Resour. Conserv. Recycl. 74, 82100. doi:10.1016/j.resconrec.2013.03.001

Cordell, D., 2010. The story of phosphorus: Sustainability implications of global phosphorus scarcity for food security. Linköping University.

Cordell, D., Drangert, J.O., White, S., 2009. The story of phosphorus: Global food security and food for thought. Glob. Environ. Chang. doi:10.1016/j.gloenvcha.2008.10.009

Cordell, D., Rosemarin, A., Schroder, J.J., Smit, A.L., 2011. Towards global phosphorus security: A systems framework for phosphorus recovery and reuse options. Chemosphere 84, 747-758. doi:10.1016/j.chemosphere.2011.02.032

Coutand, M., Cyr, M., Deydier, E., Guilet, R., Clastres, P., 2008. Characteristics of industrial and laboratory meat and bone meal ashes and their potential applications. J. Hazard. Mater. 150, 522-532. doi:10.1016/j.jhazmat.2007.04.133

Delvasto, P., Valverde, A., Ballester, A., Igual, J.M., Munoz, J.A., Gonzalez, F., Blazquez, M.L., Garcia, C., 2006. Characterization of brushite as a recrystallization product formed during bacterial solubilization of hydroxyapatite in batch cultures. Soil Biol. Biochem. 38, 2645-2654. doi:10.1016/j.soilbio.2006.03.020

Demirbas, A., 2004. Combustion characteristics of different biomass fuels. Prog. Energy Combust. Sci. 30, 219-230. doi:10.1016/j.pecs.2003.10.004

Desmidt, E., Ghyselbrecht, K., Zhang, Y., Pinoy, L., Van der Bruggen, B., Verstraete, W., Rabaey, K., Meesschaert, B., 2015. Global Phosphorus Scarcity and FullScale P-Recovery Techniques: A Review. Crit. Rev. Environ. Sci. Technol. 45, 336-384. doi:10.1080/10643389.2013.866531

Deydier, E., Guilet, R., Sharrock, P., 2003. Beneficial use of meat and bone meal combustion residue: "An efficient low cost material to remove lead from aqueous effluent.” J. Hazard. Mater. 101, 55-64. doi:10.1016/S03043894(03)00137-7

Dorozhkin, S. V, 2012. Dissolution mechanism of calcium apatites in acids: A review of literature. World J. Methodol. 2, 1-17. doi:10.5662/wjm.v2.i1.1

Dorozhkin, S. V, 1997. Surface Reactions of Apatite Dissolution. J. Colloid Interface Sci. 191, 489-497. doi:10.1006/jcis.1997.4942 
Dorozhkin, S. V, 1996. Fundamentals of the Wet-Process Phosphoric Acid Production . 1 . Kinetics and Mechanism of the Phosphate Rock Dissolution. Ind. Eng. Chem. Res. 35, 4328-4335. doi:10.1021/ie960092u

Ekpo, U., Ross, A.B., Camargo-Valero, M.A., Fletcher, L.A., 2016. Influence of pH on hydrothermal treatment of swine manure: Impact on extraction of nitrogen and phosphorus in process water. Bioresour. Technol. 214, 637-644.

Elouear, Z., Bouzid, J., Boujelben, N., Feki, M., Jamoussi, F., Montiel, A., 2008. Heavy metal removal from aqueous solutions by activated phosphate rock. J. Hazard. Mater. 156, 412-420. doi:10.1016/j.jhazmat.2007.12.036

Elser, J., Bennett, E., 2011. A broken biogeochemical cycle. Nature 478, $29-31$. doi:10.1038/478029a

Elliott, J. C., 2002. Calcium Phosphate Biominerals. Rev. Mineral. Geochem. 48(1): 427-453.

Fleet, M. E., 2009. Infrared spectra of carbonate apatites: v2-Region bands. Biomaterials 30(8): 1473-1481.

Franke, R., Hormes, J., 1995. The P K-near edge absorption spectra of phosphates. Phys. B Phys. Condens. Matter 216, 85-95. doi:10.1016/0921-4526(95)00446-7

Grzmil, B., Wronkowski, J., 2006. Removal of phosphates and fluorides from industrial wastewater. Desalination 189, 261-268. doi:10.1016/j.desal.2005.07.008

Gunkel-Grillon, P., Roth, E., Laporte-Magoni, C., Le Mestre, M., 2015. Effects of long term raw pig slurry inputs on nutrient and metal contamination of tropical volcanogenic soils, Uvéa Island (South Pacific). Sci. Total Environ. 533, 339-46. doi:10.1016/j.scitotenv.2015.06.110

Harouaka, K., Eisenhauer, A., Fantle, M.S., 2014. Experimental investigation of Ca isotopic fractionation during abiotic gypsum precipitation. Geochim. Cosmochim. Acta 129, 157-176. doi:10.1016/j.gca.2013.12.004

Havukainen, J., Nguyen, M.T., Hermann, L., Horttanainen, M., Mikkilä, M., Deviatkin, I., Linnanen, L., 2016. Potential of phosphorus recovery from sewage sludge and manure ash by thermochemical treatment. Waste Manag. 49, 221229. doi:10.1016/j.wasman.2016.01.020

He, Z., Pagliari, P.H., Waldrip, H.M., 2016. Applied and Environmental Chemistry of Animal Manure: A Review. Pedosphere 26, 779-816. doi:10.1016/S10020160(15)60087-X

Heilmann, S.M., Molde, J.S., Timler, J.G., Wood, B.M., Mikula, A.L., Vozhdayev, G. V, Colosky, E.C., Spokas, K. a, Valentas, K.J., 2014. Phosphorus Reclamation through Hydrothermal Carbonization of Animal Manures. Environ. Sci. Technol. doi:10.1021/es501872k

Huang, H., Yuan, X., 2015. Recent progress in the direct liquefaction of typical biomass. Prog. Energy Combust. Sci. 49, 59-80. doi:10.1016/j.pecs.2015.01.003

IFDC, 2010. World Phosphate Rock Reserves and Resources. International Fertilizer Development Centre.

Ingall, E. D., Brandes J. A., Diaz J. M., de Jonge M. D., Paterson D., McNulty I., Elliott W.C., Northrup P., 2011. Phosphorus K-edge XANES spectroscopy of mineral standards. J. Synchrotron Radiat 18: 189-197.

Johnsson, M.S.-A., Nancollas, G.H., 1992. The Role of Brushite and Octacalcium Phosphate in Apatite Formation. Crit. Rev. Oral Biol. Med. 3, 61-82. doi:10.1177/10454411920030010601

Kaikake, K., Sekito, T., Dote, Y., 2009. Phosphate recovery from phosphorus-rich solution obtained from chicken manure incineration ash. Waste Manag. 29, 
1084-1088. doi:10.1016/j.wasman.2008.09.008

Kleemann, R., Chenoweth, J., Clift, R., Morse, S., Pearce, P., Saroj, D., 2015. Evaluation of local and national effects of recovering phosphorus at wastewater treatment plants: Lessons learned from the UK. Resour. Conserv. Recycl. 105, 347-359. doi:10.1016/j.resconrec.2015.09.007

Komiyama, T., Kobayashi, A., Yahagi, M., 2013. The chemical characteristics of ashes from cattle, swine and poultry manure. J. Mater. Cycles Waste Manag. 15, 106-110. doi:10.1007/s10163-012-0089-2

Kongsomart, B., Kannari, N., Takarada, T., 2016. Catalytic Effects of BiomassDerived Ash on Loy Yang Brown Coal Gasification. Int. J. Biomass Renewables $5,12-22$.

Kuligowski, K., Poulsen, T.G., 2010. Phosphorus and zinc dissolution from thermally gasified piggery waste ash using sulphuric acid. Bioresour. Technol. 101, 51235130. doi:10.1016/j.biortech.2010.01.143

Kuz'mina, M.A., Zhuravlev, S. V., Frank-Kamenetskaya, O. V., 2013. The effect of medium chemistry on the solubility and morphology of brushite crystals. Geol. Ore Depos. 55, 692-697. doi:10.1134/S1075701513080072

Leng, L., Li, J., Wen, Z., Zhou, W., 2018a. Use of microalgae to recycle nutrients in aqueous phase derived from hydrothermal liquefaction process. Bioresour. Technol. 256, 529-542. doi:10.1016/j.biortech.2018.01.121

Leng, L., Li, J., Yuan, X., Li, J., Han, P., Hong, Y., Wei, F., Zhou, W., $2018 b$. Beneficial synergistic effect on bio-oil production from co-liquefaction of sewage sludge and lignocellulosic biomass. Bioresour. Technol. 251, 49-56. doi:10.1016/j.biortech.2017.12.018

Leng, L., Yuan, X., Huang, H., Jiang, H., Chen, X., Zeng, G., 2014. The migration and transformation behavior of heavy metals during the liquefaction process of sewage sludge. Bioresour. Technol. 167, 144-150. doi:10.1016/j.biortech.2014.05.119

Leng, L., Yuan, X., Shao, J., Huang, H., Wang, H., Li, H., Chen, X., Zeng, G., 2016. Study on demetalization of sewage sludge by sequential extraction before liquefaction for the production of cleaner bio-oil and bio-char. Bioresour. Technol. 200, 320-327. doi:10.1016/j.biortech.2015.10.040

Magalhães, M.C.F., Williams, P.A., 2007. Apatite Group Minerals Solubility and Environmental Remediation, in: Thermodynamics, Solubility and Environmental Issues. pp. 327-340.

Mayer, B.K., Baker, L.A., Boyer, T.H., Drechsel, P., Gifford, M., Hanjra, M.A., Parameswaran, P., Stoltzfus, J., Westerhoff, P., Rittmann, B.E., 2016. Total Value of Phosphorus Recovery. Environ. Sci. Technol. 50, 6606-6620. doi:10.1021/acs.est.6b01239

Murphy, J., Riley, J.P., 1962. A modified single solution method for the determination of phosphate in natural waters. Anal. Chim. Acta 27, 31-36. doi:10.1016/S00032670(00)88444-5

Niu, Y., Tan, H., Hui, S., 2016. Ash-related issues during biomass combustion: Alkali-induced slagging, silicate melt-induced slagging (ash fusion), agglomeration, corrosion, ash utilization, and related countermeasures. Prog. Energy Combust. Sci. 52, 1-61. doi:10.1016/j.pecs.2015.09.003

Olsen, S.R., Cole, C. V, Watandbe, F., Dean, L., 1954. Estimation of Available Phosphorus in Soil by Extraction with sodium Bicarbonate. U.S. Dep. Agric. 939.

Olson, B.M., Bremer, E., McKenzie, R.H., Bennett, R., 2010. Phosphorus 
accumulation and leaching in two irrigated soils with incremental rates of cattle manure. Can. J. Soil Sci. 90, 355-362. doi:10.4141/CJSS09025

Oshita, K., Sun, X., Kawaguchi, K., Shiota, K., Takaoka, M., Matsukawa, K., Fujiwara, T., 2016. Aqueous leaching of cattle manure incineration ash to produce a phosphate enriched fertilizer. J. Mater. Cycles Waste Manag. 18, 608617. doi:10.1007/s10163-016-0528-6

Oxmann, J. F., 2014. Technical Note: An X-ray absorption method for the identification of calcium phosphate species using peak-height ratios. Biogeosciences 11(8): 2169-2183.

Parhi, P., Ramanan, A., Ray, A.R., 2006. Hydrothermal Synthesis of nanocrystalline powders of alkaline-earth hydroxyapatites, A10(PO4)6(OH)2 $(\mathrm{A}=\mathrm{Ca}, \mathrm{Sr}$ and Ba). J. Mater. Sci. 41, 1455-1458. doi:10.1007/s10853-006-7460-4

Pettersson, A., Åmand, L.-E., Steenari, B.-M., 2008a. Leaching of ashes from cocombustion of sewage sludge and wood-Part II: The mobility of metals during phosphorus extraction. Biomass Bioenerg. 32, 236-244. doi:10.1016/j.biombioe.2007.09.006

Pettersson, A., Åmand, L.-E., Steenari, B.-M., 2008b. Leaching of ashes from cocombustion of sewage sludge and wood-Part I: Recovery of phosphorus. Biomass Bioenerg. 32, 224-235. doi:10.1016/j.biombioe.2007.09.016

Peters, F., Schwarz K., Epple M., 2000. The structure of bone studied with synchrotron X-ray diffraction, X-ray absorption spectroscopy and thermal analysis. Thermochim. Acta 361(1-2): 131-138.

Petzet, S., Peplinski, B., Cornel, P., 2012. On wet chemical phosphorus recovery from sewage sludge ash by acidic or alkaline leaching and an optimized combination of both. Water Res. 46, 3769-3780. doi:10.1016/j.watres.2012.03.068

Ragauskas, A.J., 2006. The Path Forward for Biofuels and Biomaterials. Science. 311, 484-489. doi:10.1126/science.1114736

Rajendran, J., Gialanella S., Aswath P. B., 2013. XANES analysis of dried and calcined bones. Mat. Sci. Eng. C-Mater. 33(7): 3968-3979.

Ravel, B., Newville M., 2005. ATHENA, ARTEMIS, HEPHAESTUS: data analysis for X-ray absorption spectroscopy using IFEFFIT. J. Synchrotron Radiat. 12: 537-541.

Rittmann, B.E., Mayer, B., Westerhoff, P., Edwards, M., 2011. Capturing the lost phosphorus. Chemosphere 84, 846-853. doi:10.1016/j.chemosphere.2011.02.001

Saidur, R., Abdelaziz, E.A., Demirbas, A., Hossain, M.S., Mekhilef, S., 2011. A review on biomass as a fuel for boilers. Renew. Sustain. Energy Rev. 15, 22622289. doi:10.1016/j.rser.2011.02.015

Sattari, S.Z., Bouwman, A.F., Giller, K.E., van Ittersum, M.K., 2012. Residual soil phosphorus as the missing piece in the global phosphorus crisis puzzle. Proc. Natl. Acad. Sci. U. S. A. 109, 6348-53. doi:10.1073/pnas.1113675109

Simons, A., Solomon, D., Chibssa, W., Blalock, G., Lehmann, J., 2014. Filling the phosphorus fertilizer gap in developing countries. Nat. Geosci. 7, 3-3. doi:10.1038/ngeo2049

Stegemann, J.A., Côté, P.L., 1991. Acid Neutralization Capacity, Appendix B: Investigation of test methods for solidified waste evaluation-a cooperative program, Manuscript Series TS-15, Environment Canada Wastewater Technology Centre, Burlington, Ontario Canada.

Štulajterová, R., Medvecký, L', 2008. Effect of calcium ions on transformation brushite to hydroxyapatite in aqueous solutions. Colloids Surfaces A Physicochem. Eng. Asp. 316, 104-109. doi:10.1016/j.colsurfa.2007.08.036 
Sugiyama, S., Kitora, R., Kinoshita, H., Nakagawa, K., Katoh, M., Nakasaki, K., 2016. Recovery of Calcium Phosphates from Composted Chicken Manure. J. Chem. Eng. Japan 49, 224-228. doi:10.1252/jcej.15we111

Szögi, A.A., Vanotti, M.B., Hunt, P.G., 2015. Phosphorus recovery from pig manure solids prior to land application. J. Environ. Manage. 157, 1-7.

Tan, Z., Lagerkvist, A., 2011. Phosphorus recovery from the biomass ash: A review. Renew. Sustain. Energy Rev. 15, 3588-3602. doi:10.1016/j.rser.2011.05.016

Tayibi, H., Choura, M., López, F.A., Alguacil, F.J., López-Delgado, A., 2009. Environmental impact and management of phosphogypsum. J. Environ. Manage. 90, 2377-2386. doi:10.1016/j.jenvman.2009.03.007

Tilman, D., Fargione, J., Wolff, B., D’Antonio, C., Dobson, A., Howarth, R., Schindler, D., Schlesinger, W.H., Simberloff, D., Swackhamer, D., 2001. Forecasting agriculturally driven global environmental change. Science 292, 281-284. doi:10.1126/science. 1057544

Tilman, D., Lehman, C., 1987. Human-caused environmental change : Impacts on plant diversity and evolution. Proc. Natl. Acad. Sci. U. S. A. 98, 5433-5440. doi:10.1073/pnas.091093198

Vassilev, S. V., Baxter, D., Andersen, L.K., Vassileva, C.G., 2013a. An overview of the composition and application of biomass ash. Part 2. Potential utilisation, technological and ecological advantages and challenges Fuel 105, 19-39. doi:10.1016/j.fuel.2012.10.001

Vassilev, S. V., Baxter, D., Andersen, L.K., Vassileva, C.G., 2013b. An overview of the composition and application of biomass ash. Part 1. Phase-mineral and chemical composition and classification. Fuel 105, 40-76. doi:10.1016/j.fuel.2012.09.041

Vassilev, S. V., Baxter, D., Andersen, L.K., Vassileva, C.G., Morgan, T.J., 2012. An overview of the organic and inorganic phase composition of biomass. Fuel 94, 133. doi:10.1016/j.fuel.2011.09.030

Vassilev, S. V., Baxter, D., Vassileva, C.G., 2013c. An overview of the behaviour of biomass during combustion: Part I. Phase-mineral transformations of organic and inorganic matter. Fuel 112, 391-449. doi:10.1016/j.fuel.2013.05.043

Wilfert, P., Kumar, P.S., Korving, L., Witkamp, G.J., Van Loosdrecht, M.C.M., 2015. The Relevance of Phosphorus and Iron Chemistry to the Recovery of Phosphorus from Wastewater: A Review. Environ. Sci. Technol. 49, 9400-9414. doi:10.1021/acs.est.5b00150

Williams, A.G., Leinonen, I., Kyriazakis, I., 2016. Environmental benefits of using turkey litter as a fuel instead of a fertiliser. J. Clean. Prod. 113, 167-175. doi:10.1016/j.jclepro.2015.11.044

Wu, S., Wang, L., Zhao, L., Zhang, P., El-shall, H., 2018. Recovery of rare earth elements from phosphate rock by hydrometallurgical processes - A critical review. Chem. Eng. J. 335, 774-800. doi:10.1016/j.cej.2017.10.143

Zhang, F.S., Yamasaki, S., Kimura, K., 2002. Waste ashes for use in agricultural production: II. Contents of minor and trace metals. Sci. Total Environ. 286, 111118. doi:10.1016/S0048-9697(01)00968-8 


\section{Figure captions}

Fig. 1 X-ray powder diffraction (XRD) (a), Fourier transform infrared spectra (FTIR, normalised) (b), Thermogravimetric (TG/DTG) (c), and P K-edge X-ray absorption near edge structure (XANES, normalised) (d) analyses of meat and bone meal (MBM) bottom ashes (BA) and air pollution control residue (APCr), and poultry litter co-combustion (PL) bottom ash and residues from leaching of the same residues at $\mathrm{pH}$ 5.1-6.8. The reference materials Morrocan apatite (carbonate apatite), brushite, and apatite (hydroxyapatite) were all analyzed by FTIR, TG/DTG, and XANES, but only the references most relevant to each figure were presented; XRD references were from the XRD pattern database (International Centre for Diffraction Data, ICDD).

Fig. 2 Concentration of available $\mathrm{P}$ in meat and bone meal (MBM) bottom ashes (BA) and air pollution control residue (APCr), and poultry litter co-combustion (PL) bottom ash and residues from leaching of the same residues at pH 5.1-6.8. Error bars represent standard deviation of three replicates.

Fig. 3 Anion leaching from meat and bone meal (MBM) bottom ashes (BA) and air pollution control residue (APCr), and poultry litter co-combustion (PL) bottom ash in the Acid Neutralization Capacity test (circled points are those for which the leached residue was characterised).

Fig. 4 Major element leaching from meat and bone meal (MBM) bottom ashes (BA) and air pollution control residue (APCr), and poultry litter co-combustion (PL) bottom ash in the Acid Neutralization Capacity test (circled points are those for which the leached residue was characterised). 
763

764

765

766

767

Fig. 5 P recovery (average of duplicates) from meat and bone meal (MBM) bottom ashes (BA) and air pollution control residue (APCr), and poultry litter cocombustion (PL) bottom ash using $\mathrm{H}_{2} \mathrm{SO}_{4}$ and $\mathrm{HNO}_{3}$, (a) Acid consumption comparison between $\mathrm{H}_{2} \mathrm{SO}_{4}$ and $\mathrm{HNO}_{3}$; (b) P recovery percentage using $\mathrm{H}_{2} \mathrm{SO}_{4}$. Leaching time $2 \mathrm{~h}$; Solid/liquid ratio 0.1 . 
Table 1 Acid demand for $P$ recovery

\begin{tabular}{|c|c|c|c|c|c|c|}
\hline Item & $\begin{array}{l}\text { Original } \\
\mathrm{TP} \\
\left(\mathrm{g} \mathrm{kg}^{-1}\right)\end{array}$ & $\begin{array}{l}\mathrm{TP} \\
\text { recovery } \\
\text { rate }(\%)\end{array}$ & $\begin{array}{l}\text { Acid demand } \\
(\mathrm{mol} \mathrm{H} / \\
\text { mol P) }\end{array}$ & $\begin{array}{l}\text { Method and optimal } \\
\text { conditions }\end{array}$ & Comments & Ref. \\
\hline $\begin{array}{l}\text { Swine } \\
\text { manure }\end{array}$ & $\sim 16$ & $\begin{array}{l}94 \% \\
\text { leached to } \\
\text { solution }\end{array}$ & 3.78 & $\begin{array}{l}\text { Hydrothermal } \quad \text { acid } \\
\text { leaching (S/L: } 24 \mathrm{~g} / 220 \\
\mathrm{~mL}): \quad 170 \quad{ }^{\circ} \mathrm{C}, 0.1 \quad \mathrm{M} \\
\mathrm{H}_{2} \mathrm{SO}_{4}(\mathrm{pH} \rightarrow 3.5)\end{array}$ & $\begin{array}{l}\text { Additional } \\
\text { thermal } \\
\text { consumption. }\end{array}$ & $\begin{array}{l}\text { (Ekpo et al., } \\
\text { 2016) }\end{array}$ \\
\hline $\begin{array}{l}\text { Composited } \\
\text { chicken } \\
\text { manure }\end{array}$ & - & - & 9.10 & $\begin{array}{llll}\text { Acid leaching } & \text { (S/L: } 1 \\
\mathrm{~g} / 100 \mathrm{~mL}): & 0.1 \mathrm{M} \\
\mathrm{HNO}_{3} & & & \end{array}$ & $\begin{array}{l}\text { Too much } \\
\text { wastewater. }\end{array}$ & $\begin{array}{l}\text { (Sugiyama } \\
\text { et al., 2016) }\end{array}$ \\
\hline $\begin{array}{l}\text { Fresh pig } \\
\text { manure }\end{array}$ & 4.2 & $\begin{array}{l}87 \% \\
\text { leached to } \\
\text { solution } \\
88 \% \\
\text { leached to } \\
\text { solution }\end{array}$ & 6.36 & $\begin{array}{l}\text { Acid leaching }(\mathrm{S} / \mathrm{L}: 2 \\
\mathrm{g} / 50 \mathrm{~mL}): 10 \mathrm{mM} \text { citric } \\
(\mathrm{pH} 6.9 \rightarrow 3.2) \\
\text { Acid leaching }(\mathrm{S} / \mathrm{L}: 2 \\
\mathrm{g} / 50 \mathrm{~mL}): 40 \mathrm{mM} \mathrm{HCl} \\
(\mathrm{pH} 7.0 \rightarrow 1.8)\end{array}$ & $\begin{array}{l}\text { Extracted } \\
\text { residues are } \\
\text { safer for land } \\
\text { application } \\
\text { with a more } \\
\text { balanced N: } \\
\mathrm{P} \text { ratio. Too } \\
\text { much } \\
\text { wastewater. }\end{array}$ & $\begin{array}{l}\text { (Szögi et } \\
\text { al., 2015) }\end{array}$ \\
\hline $\begin{array}{l}\text { Poultry } \\
\text { manure } \\
\text { hydrochar }\end{array}$ & 32.9 & $\begin{array}{l}89.7 \% \\
\text { leached to } \\
\text { solution }\end{array}$ & 92.2 & $\begin{array}{l}\text { Acid leaching (S/L: } 10 \\
\mathrm{~g} / 220 \mathrm{~mL}): 4 \mathrm{M} \mathrm{HCl}\end{array}$ & $\begin{array}{ll}\text { High } & \text { acid } \\
\text { load. } & \text { Too } \\
\text { much } & \end{array}$ & $\begin{array}{l}\text { (Heilmann } \\
\text { et al., } \\
\text { 2014) }\end{array}$ \\
\hline $\begin{array}{l}\text { Swine } \\
\text { manure } \\
\text { hydrochar }\end{array}$ & 39.1 & $\begin{array}{l}89.3 \% \\
\text { leached to } \\
\text { solution }\end{array}$ & 78.1 & & wastewater. & \\
\hline $\begin{array}{l}\text { Cow } \\
\text { manure } \\
\text { hydrochar }\end{array}$ & 18.6 & $\begin{array}{l}98.4 \% \\
\text { leached to } \\
\text { solution }\end{array}$ & 149.1 & & & \\
\hline $\begin{array}{l}\text { Pig manure } \\
\text { pyrolysis } \\
\text { char }\end{array}$ & $41.2-54.6$ & $\begin{array}{l}\sim 0 \% \\
\text { leached to } \\
\text { solution }\end{array}$ & $126.2-167.2$ & $\begin{array}{l}\text { Acid leaching (S/L: } 2 \\
\mathrm{~g} / 1000 \mathrm{~mL}): 0.2 \mathrm{M} \\
\mathrm{H}_{2} \mathrm{SO}_{4}\end{array}$ & $\begin{array}{l}\text { High acid } \\
\text { load. Too } \\
\text { much } \\
\text { wastewater. }\end{array}$ & $\begin{array}{l}\text { (Azuara et } \\
\text { al., 2013) }\end{array}$ \\
\hline $\begin{array}{l}\text { Gasified } \\
\text { piggery } \\
\text { waste ash }\end{array}$ & - & $\begin{array}{l}94 \% \\
\text { leached to } \\
\text { solution }\end{array}$ & 6.61 & $\begin{array}{l}\text { Acid leaching: (S/L: } 1 \\
\text { g/12.5 mL): } 0.8 \quad \mathrm{M} \\
\mathrm{H}_{2} \mathrm{SO}_{4}\end{array}$ & $\begin{array}{l}\text { Higher } \\
\mathrm{H}_{2} \mathrm{SO}_{4} \\
\text { concentration } \\
\text { did not } \\
\text { improve P } \\
\text { dissolution. }\end{array}$ & $\begin{array}{l}\text { (Kuligowski } \\
\text { and } \\
\text { Poulsen, } \\
\text { 2010) }\end{array}$ \\
\hline $\begin{array}{l}\text { Animal } \\
\text { carcasses } \\
\text { incineration } \\
\text { ash }\end{array}$ & 138.4 & $\begin{array}{l}57 \% \\
\text { leached to } \\
\text { solution } \\
73 \% \\
\text { leached to } \\
\text { solution }\end{array}$ & 3.10 & $\begin{array}{l}\text { Acid leaching: } \mathrm{H}_{2} \mathrm{SO}_{4} \\
\text { (pH 2.0) } \\
\text { Acid leaching: } \mathrm{H}_{2} \mathrm{SO}_{4} \\
\text { (pH 1.5) }\end{array}$ & $\begin{array}{l}\text { Feasible } \\
\text { practice }\end{array}$ & $\begin{array}{l}\text { (Cohen, } \\
\text { 2009) }\end{array}$ \\
\hline $\begin{array}{l}\text { MBM } \\
\text { ashes/PL } \\
\text { ashes }\end{array}$ & 84.6-139 & $\begin{array}{l}\text { About } 90 \% \\
\text { leached to } \\
\text { solution }\end{array}$ & $3.1-5.3$ & $\begin{array}{l}\text { Acid leaching: } \mathrm{H}_{2} \mathrm{SO}_{4} \\
\text { or } \mathrm{HNO}_{3}(\mathrm{~S} / \mathrm{L}: 1 \mathrm{~g} / 10 \\
\mathrm{mL}, \mathrm{pH} \text { around } 1.0-1.5)\end{array}$ & $\begin{array}{l}\text { Feasible } \\
\text { practice }\end{array}$ & This study \\
\hline
\end{tabular}


Table 2 Elemental analyses of UK biomass bottom ashes (BA) and air pollution control residue (APCr) determined by digestion and ICP-OES, including also total $\mathrm{P}$ by colorimetry $\left(^{*}\right)$

\begin{tabular}{|c|c|c|c|c|c|}
\hline Element & MBM1-BA & MBM2-BA & MBM2-APCr & PL1-BA & PL2-BA \\
\hline \multicolumn{6}{|c|}{ Major element (mg/g) } \\
\hline$\overline{\mathrm{Al}}$ & 3.70 & 1.78 & 1.58 & 6.07 & 3.58 \\
\hline $\mathrm{Ca}$ & 316 & 245 & 246 & 175 & 161 \\
\hline $\mathrm{Fe}$ & 15.3 & 4.04 & 2.51 & 7.34 & 5.99 \\
\hline K & 7.97 & 50.9 & 27.0 & 88.5 & 119 \\
\hline $\mathrm{Mg}$ & 7.66 & 7.23 & 6.13 & 37.0 & 45.2 \\
\hline $\mathrm{Mn}$ & 0.23 & 0.18 & 0.08 & 3.14 & 4.09 \\
\hline $\mathrm{Na}$ & 22.5 & 88.0 & 72.7 & 18.3 & 21.7 \\
\hline $\mathrm{P}$ & 131 & 95.4 & 97.9 & 82.8 & 109 \\
\hline $\mathrm{TP}^{*}$ & 139 & 96.3 & 98.8 & 84.6 & 111 \\
\hline \multicolumn{6}{|c|}{ Minor element (mg/kg) } \\
\hline$\overline{\mathrm{B}}$ & 113 & 37.6 & 23.0 & 146.8 & 186 \\
\hline $\mathrm{Ba}$ & 156 & 99.0 & 92.0 & 228 & 156 \\
\hline $\mathrm{Bi}$ & 1.4 & 0.4 & 1.2 & ND & ND \\
\hline $\mathrm{Cd}$ & ND & ND & ND & ND & ND \\
\hline $\mathrm{Cr}$ & 16.7 & 34.4 & 26.2 & 48.8 & 35.2 \\
\hline Co & 10.5 & 8.6 & 0.9 & 6.5 & 16.1 \\
\hline $\mathrm{Cu}$ & 183 & 141 & 67.8 & 806 & 640 \\
\hline $\mathrm{Li}$ & ND & ND & ND & 1.4 & ND \\
\hline $\mathrm{Ni}$ & 6.6 & 7.4 & 5.5 & 35.1 & 22.4 \\
\hline $\mathrm{Pb}$ & 4.7 & 41.2 & 22.8 & 48.8 & 2.7 \\
\hline $\mathrm{Sr}$ & 191 & 125 & 130 & 198 & 211 \\
\hline $\mathrm{Zn}$ & 157 & 830 & 529 & 1110 & 760 \\
\hline
\end{tabular}


Table 3 Mineral phases identified in meat and bone meal (MBM) bottom ashes (BA) and air pollution control residue (APCr), and poultry litter co-combustion (PL) bottom ash and residues from leaching of the same residues at $\mathrm{pH}$ 5.1-6.8

\begin{tabular}{|c|c|c|c|c|c|c|c|c|c|c|}
\hline \multirow[t]{2}{*}{ Sample } & \multicolumn{10}{|l|}{ Mineral phases } \\
\hline & $\begin{array}{l}\text { Hydroxyapatite, } \\
\mathrm{Ca}_{5}\left(\mathrm{PO}_{4}\right)_{3}(\mathrm{OH})\end{array}$ & $\begin{array}{l}\text { Arcanite, } \\
\mathrm{K}_{2} \mathrm{SO}_{4}\end{array}$ & $\begin{array}{l}\text { Brushite, } \\
\mathrm{CaHPO}_{4} \cdot 2 \mathrm{H}_{2} \mathrm{O}\end{array}$ & $\begin{array}{l}\text { Calcite, } \\
\mathrm{CaCO}_{3}\end{array}$ & $\begin{array}{l}\text { Calcium } \\
\text { Sulfate, } \\
\mathrm{CaSO}_{4}\end{array}$ & $\begin{array}{l}\text { Gypsum, } \\
\mathrm{CaSO}_{4} \cdot 2 \mathrm{H}_{2} \mathrm{O}\end{array}$ & $\begin{array}{l}\text { Halite, } \\
\mathrm{NaCl}\end{array}$ & $\begin{array}{l}\text { Portlandite, } \\
\mathrm{Ca}(\mathrm{OH})_{2}\end{array}$ & $\begin{array}{l}\text { Potassium } \\
\text { sodium calcium } \\
\text { phosphate, } \\
\mathrm{KNaCa}_{2}\left(\mathrm{PO}_{4}\right)_{2}\end{array}$ & $\begin{array}{l}\text { Quartz, } \\
\mathrm{SiO}_{2}\end{array}$ \\
\hline MBM1-BA & + & & & + & + & & & + & & + \\
\hline $\begin{array}{l}\text { MBM1-BA } \\
\text { residue (pH 6.2) }\end{array}$ & + & & + & & & + & & & & + \\
\hline MBM2-BA & + & + & & + & + & & + & + & & + \\
\hline $\begin{array}{l}\text { MBM2-BA } \\
\text { residue (pH 5.1) }\end{array}$ & + & & + & & & + & & & & + \\
\hline MBM2-APCr & + & + & & + & + & & + & + & & \\
\hline $\begin{array}{l}\text { MBM2-APCr } \\
\text { residue (pH 5.9) }\end{array}$ & + & & + & & & + & & & & \\
\hline PL1-BA & & + & & & + & & & & + & + \\
\hline $\begin{array}{l}\text { PL1-BA residue } \\
(\mathrm{pH} \text { 6.5) }\end{array}$ & & & + & & & + & & & & + \\
\hline PL2-BA & & + & & & + & & & & + & + \\
\hline $\begin{array}{ll}\text { PL2-BA residue } \\
(\mathrm{pH} 6.8)\end{array}$ & & & + & & & + & & & & + \\
\hline
\end{tabular}



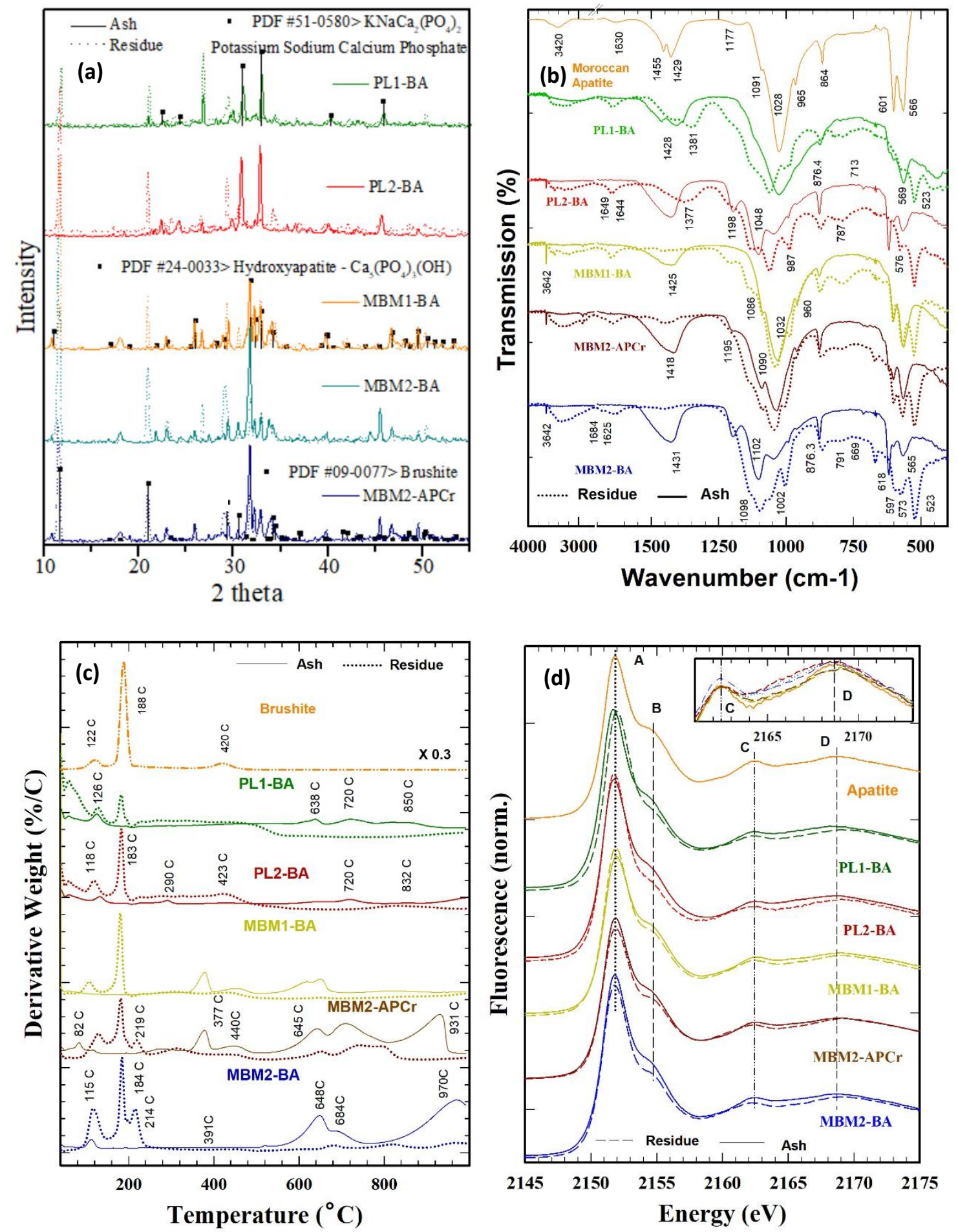

Fig. 1 X-ray powder diffraction (XRD) (a), Fourier transform infrared spectra (FTIR, normalised) (b), Thermogravimetric (TG/DTG) (c), and P K-edge X-ray absorption near edge structure (XANES, normalised) (d) analyses of meat and bone meal (MBM) bottom ashes (BA) and air pollution control residue (APCr), and poultry litter co-combustion (PL) bottom ash and residues from leaching of the same residues at $\mathrm{pH}$ 5.1-6.8. The reference materials Morrocan apatite (carbonate apatite), brushite, and apatite (hydroxyapatite) were all analyzed by FTIR, TG/DTG, and XANES, but only the references most relevant to each figure were presented; XRD references were from the XRD pattern database (International Centre for Diffraction Data, ICDD). 


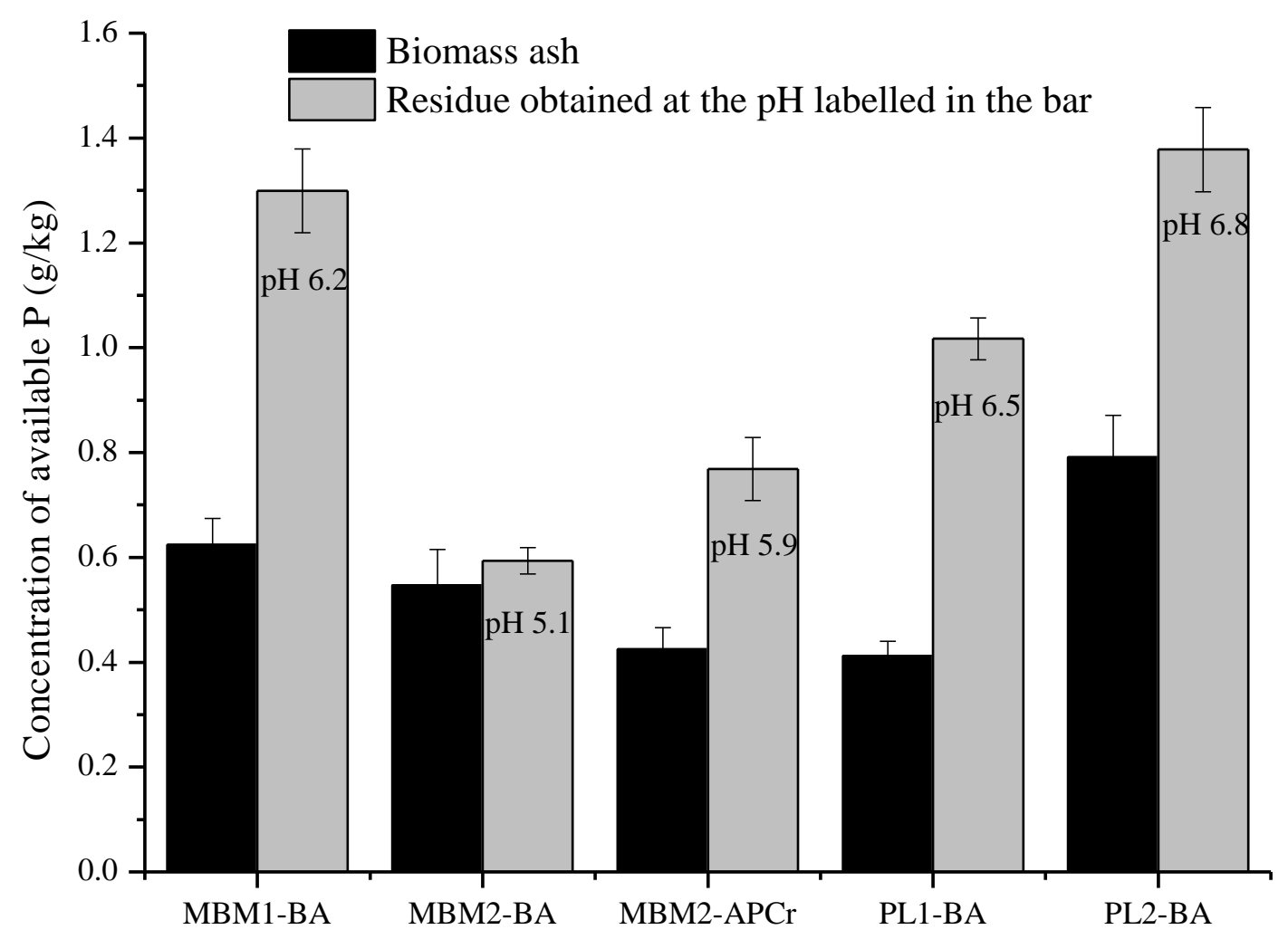

Fig. 2 Concentration of available $\mathrm{P}$ in meat and bone meal (MBM) bottom ashes (BA) and air pollution control residue (APCr), and poultry litter co-combustion (PL) bottom ash and residues from leaching of the same residues at $\mathrm{pH}$ 5.1-6.8. Error bars represent the standard deviation of three replicates. 

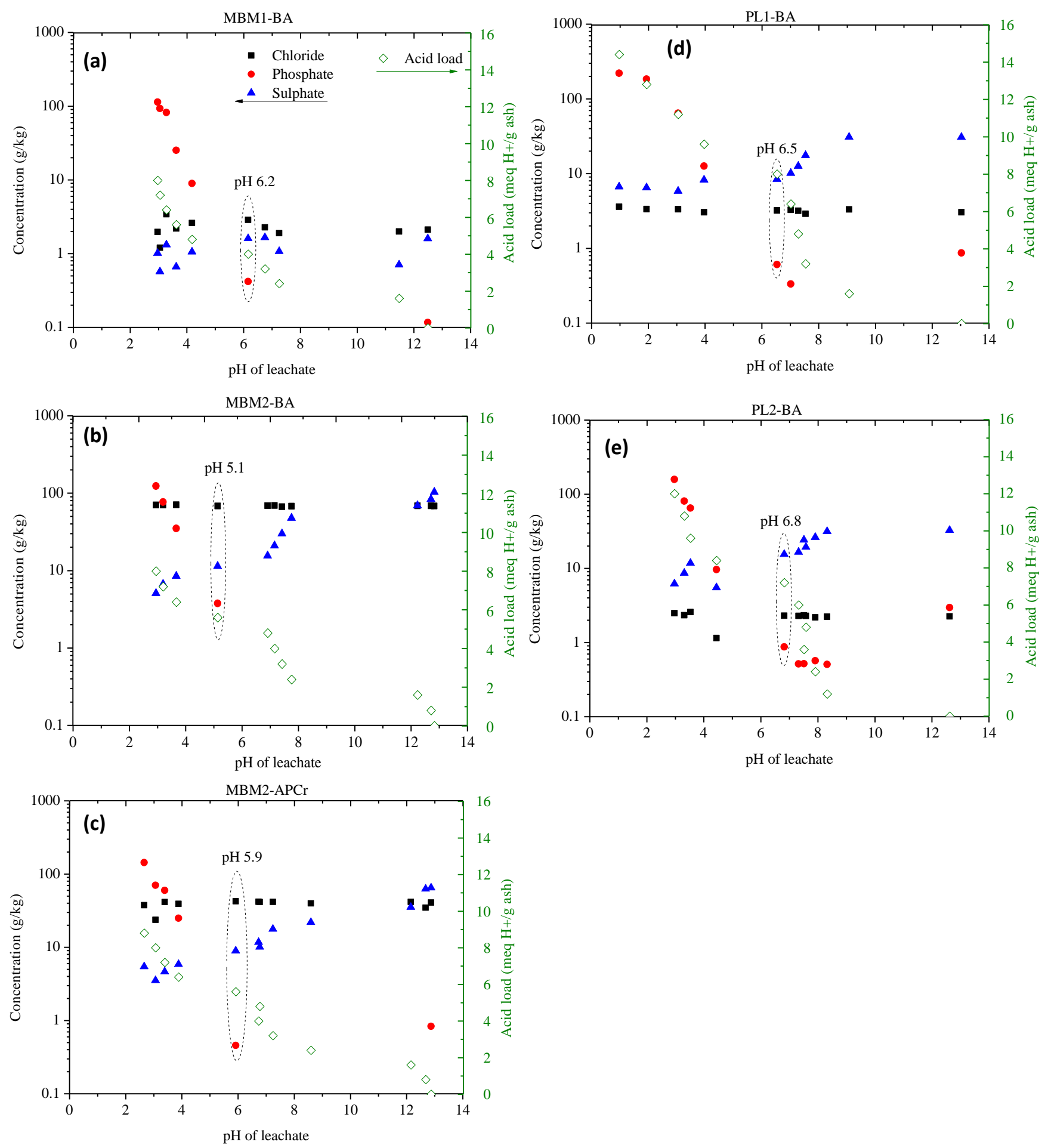

Fig. 3 Anion leaching from meat and bone meal (MBM) bottom ashes (BA) and air pollution control residue (APCr), and poultry litter co-combustion (PL) bottom ash in the Acid Neutralization Capacity test (circled points are those for which the leached residue was characterised). 

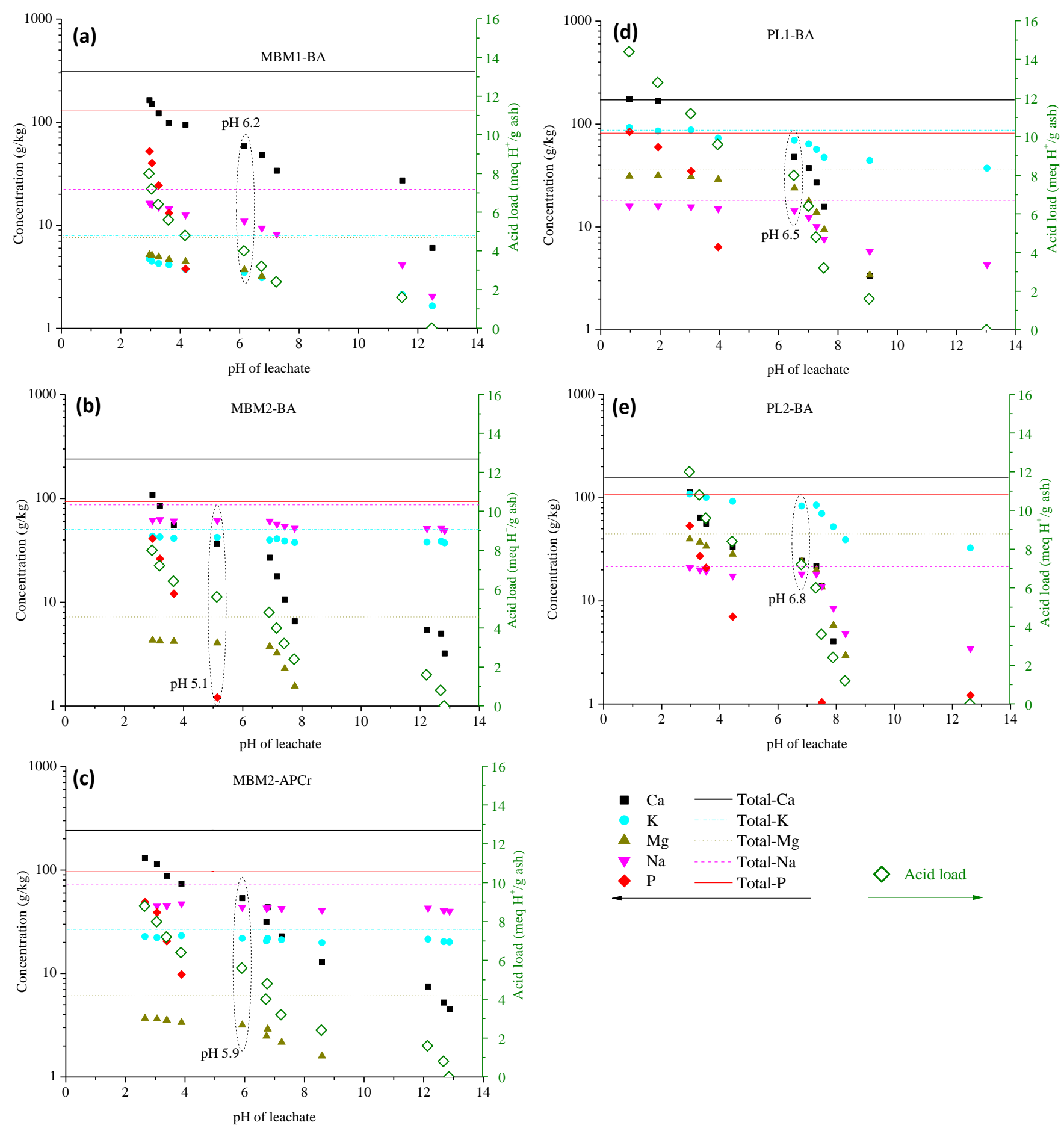

Fig. 4 Major element leaching from meat and bone meal (MBM) bottom ashes (BA) and air pollution control residue (APCr), and poultry litter co-combustion (PL) bottom ash in the Acid Neutralization Capacity test (circled points are those for which the leached residue was characterised). 

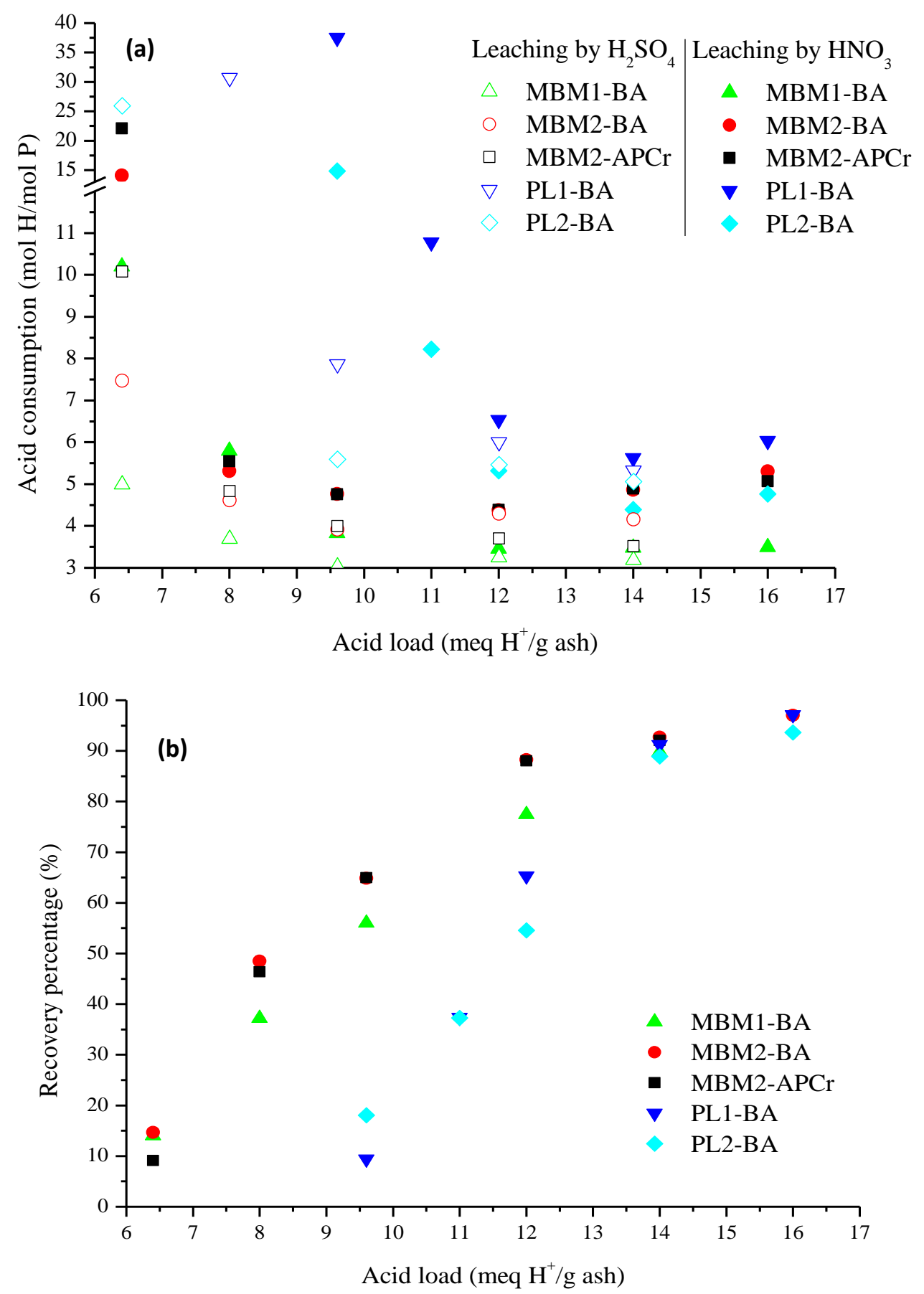

Fig. $5 \mathrm{P}$ recovery (average of duplicates) from meat and bone meal (MBM) bottom ashes (BA) and air pollution control residue (APCr), and poultry litter co-combustion (PL) bottom ash using $\mathrm{H}_{2} \mathrm{SO}_{4}$ and $\mathrm{HNO}_{3}$, (a) Acid consumption comparison between $\mathrm{H}_{2} \mathrm{SO}_{4}$ and $\mathrm{HNO}_{3}$; (b) $\mathrm{P}$ recovery percentage using $\mathrm{H}_{2} \mathrm{SO}_{4}$. Leaching time $2 \mathrm{~h}$; Solid/liquid ratio 0.1 . 

Supplementary material for on-line publication only
Click here to download Supplementary material for o Supplementary material for on-line publication only
Click here to download Supplementary material for on-line publication only: Leng et al 2018-biomass ashes \& P recovery-SI.doc Click here to download Supplementary material for on-line publication only: Leng et al 2018-biomass ashes \& P recovery-SI.doc
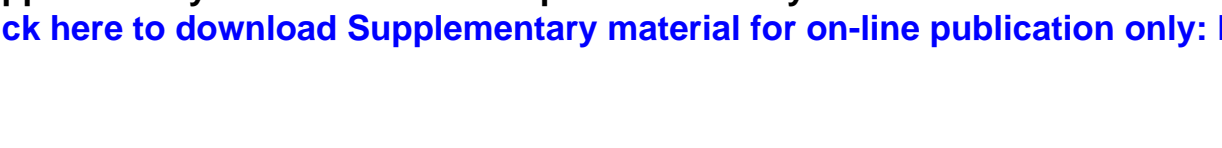